1 Running Title: Trp-derived defenses against Tetranychus urticae

2 Author for Contact details: Vojislava Grbić

3

4 Multiple indole glucosinolates and myrosinases defend Arabidopsis against 5 Tetranychus urticae herbivory

6 Emilie Widemann ${ }^{\mathrm{a}}$, Kristie Bruinsma ${ }^{\mathrm{a}}$, Brendan Walshe-Roussel ${ }^{\mathrm{a}, \mathrm{c}}$, Repon Kumer

7 Saha $^{\mathrm{a}, \mathrm{b}}$, David Letwin ${ }^{\mathrm{a}}$, Vladimir Zhurov ${ }^{\mathrm{a}}$, Mark A. Bernards ${ }^{\mathrm{a}}$, Miodrag Grbić ${ }^{\mathrm{a}}$, Vojislava

8 Grbić $^{\mathrm{a}}{ }^{*}$

$9{ }^{a}$ Department of Biology, The University of Western Ontario, 1151 Richmond Street,

10 London, ON N6A 5B7, Canada.

${ }^{\mathrm{b}}$ Present address: Department of Microbiology and Immunology, Schulich School of Medicine and Dentistry, The University of Western Ontario, London, ON N6A 3K7,

13 Canada.

${ }^{\mathrm{c}}$ Present address: Natural and Non-Prescription Health Products Directorate Health Canada, 250 Lanark Ave, Ottawa, ON, K1A 0K9, Canada.

16 * corresponding author

17 Email address of author for contact: vgrbic@uwo.ca

18 Phone number of author for contact: +15196612111

Email address for all authors: Emilie Widemann: ewidema4@uwo.ca; Kristie Bruinsma: kbruinsm@uwo.ca; Brendan Walshe-Roussel: brendan.w.roussel@gmail.com;

Repon Kumer Saha: rsaha7@uwo.ca; David Letwin: dletwin3@uwo.ca; Vladimir Zhurov: vzhurov2@uwo.ca; Mark A. Bernards: bernards@uwo.ca; Miodrag Grbić: mgrbic@uwo.ca; Vojislava Grbić: vgrbic@uwo.ca

One sentence summary

Three indole glucosinolates and the myrosinases TGG1/TGG2 help protect Arabidopsis

\title{
List of author contributions
}

V.G. and E.W. conceived the original screening and research plans; V.G. supervised the experiments; E.W. performed the fecundity assays, the two-choices and no-choice experiments, the supplementation of wild-type and mutant Arabidopsis leaves with indole glucosinolates, the extraction of leaf metabolites and HPLC-data analysis, the experiment for direct application of I3M on mites, the experiment with IGs applied in bean leaf; K.B. performed plant damage assay as well as mortality and developmental assays; B.W.R. optimized the protocol for IG analysis; B.W.R. and R.K.S. developed the protocol for the 
coumarin; V.G., E.W., V.Z. and K.B. analyzed the data; E.W. provided the draft of the manuscript with contributions from K.B, R.S. and V.Z., which was edited by V.G. with feedback provided by all authors. M.A.B., M.G. and V.G. contributed resources and equipment; V.G. is the author responsible for contact and communication.

\section{Funding information}

This work was supported by the Government of Canada through the Ontario Research

\section{ABSTRACT}

Arabidopsis defenses against herbivores are regulated by the jasmonate hormonal signaling pathway, which leads to the production of a plethora of defense compounds, including tryptophan-derived metabolites produced through CYP79B2/CYP79B3. Jasmonate signaling and CYP79B2/CYP79B3 limit Arabidopsis infestation by the generalist herbivore two-spotted spider mite, Tetranychus urticae. However, the phytochemicals responsible for Arabidopsis protection against T. urticae are unknown. Here, using Arabidopsis mutants that disrupt metabolic pathways downstream of CYP79B2/CYP79B3, and synthetic indole glucosinolates, we identified phytochemicals involved in the defense against $T$. urticae. We show that Trp-derived metabolites depending on CYP71A12 and CYP71A13 are not affecting mite herbivory. Instead, the supplementation of cyp79b2 cyp79b3 mutant leaves with the 3-indolylmethyl glucosinolate and its derived metabolites demonstrated that the indole glucosinolate pathway is sufficient to assure CYP79B2/CYP79B3-mediated defenses against $T$. urticae. We demonstrate that three indole glucosinolates can limit T. urticae herbivory, but that they have to be processed by the myrosinases to hinder T. urticae oviposition.

63 Finally, the supplementation of the mutant myc2 myc3 myc4 with indole glucosinolates indicated that the transcription factors MYC2/MYC3/MYC4 induce additional indole glucosinolate-independent defenses that control $T$. urticae herbivory. Together, these results reveal the complexity of Arabidopsis defenses against $T$. urticae that rely on

68 multiple indole glucosinolates, specific myrosinases, and additional 69 MYC2/MYC3/MYC4-dependent defenses.

71 Keywords: two-spotted spider mite, chemoprotection, herbivory, defenses, jasmonates, 72 feeding suppressants 


\section{INTRODUCTION}

The jasmonate (JA) hormonal pathway is a conserved inducer of anti-herbivory defenses in a wide range of plants. In response to herbivory, JA accumulates and triggers JAinduced defense responses that vary in different plant species and include the synthesis of defensive metabolites, volatiles, and/or proteins (Howe and Jander 2008; Lortzing and Steppuhn 2016; Wasternack and Strnad 2018; Wang et al., 2019). In Arabidopsis thaliana, JA signaling is mediated by the MYC2, MYC3, and MYC4 transcription factors that activate a wide range of defense-associated genes (Schweizer et al., 2013). Glucosinolates are defense compounds found primarily in Brassicaceae species (Fahey et al., 2001), including Arabidopsis, whose synthesis is regulated by direct interaction between MYC2/MYC3/MYC4 and MYB transcription factors (Schweizer et al., 2013). Glucosinolates are synthesized from amino acids. Aliphatic and indole glucosinolates, derived from methionine and tryptophan respectively, are the most abundant glucosinolates in Arabidopsis (Brown et al., 2003). They are represented by a family of related compounds with 13 aliphatic and 3 stable indole metabolites (Brown et al., 2003; Mahmut 2020). These compounds have varying defensive specificities, so that some herbivores, like Manduca sexta and Trichoplusia $n i$ are sensitive to aliphatic glucosinolates (Müller et al., 2010), some like Myzus persicae to indole glucosinolates (Kim and Jander 2007) and some, like Spodoptera littoralis and Mamestra brassicae, to both classes of compounds (Müller et al., 2010; Jeschke et al., 2017). Synthesized glucosinolates have to undergo further modifications to become biologically active. They are hydrolyzed by beta-glucosidases referred to as myrosinases (Bjorkman 1976; Bhat and Vyas 2019). Classical myrosinases TGG1 and TGG2 cleave the glucose group from a glucosinolate and release a highly reactive aglycone that gives rise to isothiocyanates, nitriles, epithionitriles, or thiocyanates (Barth and Jander 2006; Bones and Rossiter 2006; Blažević et al., 2020). Glucosinolates and the myrosinases TGG1 and TGG2 accumulate at high levels in different cell types, so tissue damage that is associated with herbivory is required for their contact (Xue et al., 1995; Husebye et al., 2002; Barth and Jander 2006; Ueda et al., 2006; Zhao et al., 2008; Sønderby et al., 2010; Shroff et al., 2015). Besides classical myrosinases, additional beta-glucosidases (BGLU) were demonstrated to have myrosinase activities against indole glucosinolates (Bednarek et al., 2009; Nakano et al., 2017; Nakazaki et al., 2019). They co-localize with glucosinolates but accumulate in different cell compartments.

The chelicerate Tetranychus urticae (the two-spotted spider mite) is an extreme generalist herbivore that uses its stylet to transverse the leaf epidermis and reach leaf mesophyll where it feeds from individual cells (Bensoussan et al., 2016). Mite feeding on Arabidopsis triggers the accumulation of JA and the induction of MYC2/MYC3/MYC4mediated responses (Zhurov et al., 2014). Aliphatic glucosinolates are not effective against mites, however, mite fitness increases on the cyp79b2 cyp79b3 mutant plants, indicating that the Trp-derived secondary metabolite(s) restrict mite herbivory (Zhurov et 
al., 2014). CYP79B2 and CYP79B3 are required for the conversion of tryptophan to indole-3-acetaldoxime (IAOx) that is further processed by CYP71A13, CYP71A12, and CYP83B1 to initiate biosynthesis of camalexin, cyanogenic metabolite 4-OH-ICN and indole glucosinolate (IG) defense compounds, respectively (Zhao et al., 2002; SanchezVallet et al., 2010; Rajniak et al., 2015; Vik et al., 2018; Glindemann et al., 2019; Pastorczyk et al., 2020). 3-Indolylmethyl glucosinolate (I3M) is a parental indole glucosinolate that is further hydroxylated by cytochromes P450 of the CYP81 family and methylated by IG methyltransferases. If modifications occur on the nitrogen of the indole ring, $\mathrm{I} 3 \mathrm{M}$ gives rise to $1 \mathrm{OH}-\mathrm{I} 3 \mathrm{M}$ (intermediate that does not accumulate in Arabidopsis) and 1-Methoxy-I3M (1MO-I3M). If carbon 4 of the indole ring is modified, $4 \mathrm{OH}-\mathrm{I} 3 \mathrm{M}$ and 4MO-I3M are synthesized (Rask et al., 2000; Meier et al., 2019).

While it was established that the JA pathway and CYP79B2/CYP79B3 are required for Arabidopsis defenses against T. urticae, the identity of the Trp-derived metabolite(s) remained elusive. The mutant pad3, deficient in the last step of camalexin production, is not more sensitive to mite infestation than wild-type (WT) plants (Zhurov et al., 2014). However, the existence of other potential defensive compounds against mites derived from Trp via CYP71A13- or CYP71A12-dependent pathways has not been tested. Furthermore, even though it was demonstrated that I3M and $1 \mathrm{MO}-\mathrm{I} 3 \mathrm{M}$ accumulate in mite-infested Arabidopsis leaves (Zhurov et al., 2014), their effects on mite fitness have not been demonstrated. In this study, we used a collection of Arabidopsis mutants to identify which of the Trp-derived pathways protect Arabidopsis against mite herbivory. We demonstrate that of the three CYP79B2/CYP79B3-dependent pathways, the I3M, 1MO-I3M, and 4MO-I3M glucosinolate metabolites are sufficient to protect Arabidopsis plants against T. urticae. We show that intact glucosinolates cannot limit mite's ability to feed on Arabidopsis, but that they require further modifications with TGG1/TGG2 myrosinases and other currently unknown Arabidopsis factors to gain defensive activity. Furthermore, we demonstrate that in addition to Trp-derived defensive metabolites, Arabidopsis synthesizes additional indole glucosinolate-independent defenses. Our work establishes the complexity of Arabidopsis defenses that shape the interaction between Arabidopsis and generalist T. urticae.

\section{RESULTS}

\section{Trp-derived metabolites suppress feeding of adult mites}

To determine the effect of Trp-derived metabolites on mites, we performed mite feeding experiments on cyp79b2 cyp $79 b 3$ leaves that lack Trp-derived metabolites and fully defended Columbia-0 (Col-0) wild-type leaves. Repellent activity of Trp-derived defenses was challenged using a choice experiment where adult female mites could have selected either a cyp79b2 cyp79b3 or a Col-0 leaf to feed on. To track leaf genotypes 
mites fed on, we stained one of the two leaves with blue dye. When mites fed on bluestained leaves they excreted blue feces, Fig. 1A, so the frequency of blue vs. normal feces then allowed us to distinguish and quantify mite feeding on individual leaves. A similar number of blue and non-stained feces in control experiments with leaves of the same genotype indicated that the blue staining did not interfere with mite feeding and feces excretion (Fig. 1B). When mites had the choice to feed on Col-0 or cyp79b2 cyp79b3 leaves, they showed a strong preference for feeding on cyp $79 b 2$ cyp79b3 leaves (48 and 43 feces associated with feeding on cyp79b2 cyp $79 b 3$ leaves relative to 13 and 23 associated with Col-0 leaves, when cyp79b2 cyp79b3 leaves were non-stained or blue, respectively), Fig. 1B. Importantly, mites fed on Col-0 leaves even when cyp79b2 cyp79b3 leaves were present, indicating that Trp-derived metabolites do not deter mites from probing fully-defended leaves. To further characterize the impact of Trp-derived metabolites on mites we performed a no-choice feeding experiment that included mite transfer between leaves of different genotypes. Mites were allowed to feed on leaf 1 for $18 \mathrm{~h}$ and were subsequently transferred to leaf 2 for $24 \mathrm{~h}$, upon which the number of feces and eggs was recorded (Fig. 1C). Consistent with the previous report (Zhurov et al., 2014), mites that exclusively fed on cyp79b2 cyp79b3 leaves deposited about 3 times more feces (measuring mite feeding) and eggs (measuring mite fitness) relative to mites that fed on Col-0 leaves. When mites were transferred from cyp79b2 cyp79b3 to Col-0, they deposited the similar number of feces and eggs as mites that exclusively fed on Col0 , highlighting the immediate impact of Trp-derivatives on mite feeding. When mites were transferred from Col-0 to cyp79b2 cyp79b3, they deposited a slightly but significantly lower number of feces and eggs than mites fed only on cyp $79 b 2$ cyp $79 b 3$, Fig. 1C, demonstrating that the effects of Trp-derived metabolites quickly diminished once they are removed from a diet. The overall similarity between numbers of feces and eggs deposited by mites irrespective of leaf genotypes indicates that Trp-derived metabolites do not impair mite's ability to acquire nutrients from ingested plant cell content. Rather, our data point to their feeding suppressant effect, causing cessation or slowing of adult female mite feeding.

\section{I3M is sufficient to restore Arabidopsis defenses against mite infestation in cyp79b2 cyp $79 b 3$ mutant plants}

Tryptophan-derived metabolites are synthesized through CYP71A12, CYP71A13, and CYP83B1 pathways (Zhao et al., 2002; Glawischnig 2007; Rajniak et al., 2015; Pastorczyk et al., 2020). To test if metabolites produced through CYP71A12 and/or CYP71A13 pathways affect mite fitness we compared mite fecundity upon feeding on the cyp7la12 and cyp71a13 single mutants and cyp71a12 cyp71a13 (cyp71a12a13) double mutant, cyp79b2 cyp79b3, and Col-0. As seen in Figure 2A, mite fecundity was similar when they fed on mutant and Col-0 plants, indicating that Trp-derived metabolites 
synthesized through CYP71A12- and CYP71A13-pathways are not required for the Arabidopsis defense against T. urticae. To test if the third, CYP83B1-dependent, indole glucosinolate pathway is sufficient to restore cyp $79 b 2$ cyp $79 b 3$ defenses against mites, we infiltrated $2.4 \mathrm{mM}$ or $4.8 \mathrm{mM}$ I3M to cyp79b2 cyp79b3 and Col-0 detached leaves and subsequently challenged them with $T$. urticae, whose fecundity was determined $48 \mathrm{~h}$ later (Fig. 2B and C, and Supplemental Fig. S1). The treatment restored physiological levels of I3M in cyp79b2 cyp79b3 and increased levels of I3M in Col-0 treated leaves (Fig. 2B). The addition of I3M to cyp79b2 cyp79b3 leaves fully restored Arabidopsis defenses against mites, Fig. $2 \mathrm{C}$ and Supplemental Fig. S1, indicating that $\mathrm{I} 3 \mathrm{M}$ is sufficient to establish Trp-derived defenses against $T$. urticae. The supplementation of Col-0 leaves with I3M did not affect mite fecundity, implying that physiological levels of I3M are saturating defenses that could not be further enhanced by a further increase of I3M levels (Fig. 2C).

\section{Multiple indole glucosinolates defend Arabidopsis leaves against mite herbivory}

In Col-0 plants, endogenous I3M is oxidized and methylated to give rise to $1 \mathrm{MO}-\mathrm{I} 3 \mathrm{M}$ and $4 \mathrm{MO}-\mathrm{I} 3 \mathrm{M}$. To determine whether exogenously supplied I3M was processed in cyp79b2 cyp79b3 leaves infested by T. urticae, we measured levels of 1MO-I3M and 4MO-I3M in these leaves using an HPLC-MS. As expected, IG metabolites were undetectable in water-treated cyp79b2 cyp79b3 leaves, regardless of mite infestation status (Fig. 3A). However, in cyp79b2 cyp79b3 leaves supplemented with I3M, the levels of $1 \mathrm{MO}-\mathrm{I} 3 \mathrm{M}$ and $4 \mathrm{MO}-\mathrm{I} 3 \mathrm{M}$ reached about 100 and $50 \%$, respectively, of levels found in mite-infested Col-0 leaves kept in water.Therefore, the I3M infiltrated into cyp79b2 cyp79b3 leaves was partially processed by CYP81 enzymes and IG methyltransferases into $1 \mathrm{MO}-\mathrm{I} 3 \mathrm{M}$ and $4 \mathrm{MO}-\mathrm{I} 3 \mathrm{M}$, raising the question of which of these metabolites have defensive properties against T. urticae.

To test the ability of I3M-derived metabolites to reduce mite fitness we infiltrated $2.4 \mathrm{mM}$ solution of 1MO-I3M and 4MO-I3M into cyp79b2 cyp79b3 and Col-0 detached leaves. Relative to the physiological levels found in Col-0 infested leaves kept in water, the addition of $1 \mathrm{MO}-\mathrm{I} 3 \mathrm{M}$ and $4 \mathrm{MO}-\mathrm{I} 3 \mathrm{M}$ resulted in a large excess of these compounds in cyp79b2 cyp79b3 (21 and 31 fold increase, respectively) and Col-0 leaves (26 and 44 fold change, respectively) (Fig. 3A). Infiltrated leaves were inoculated with ten mites per leaf and the number of eggs and the number of feces were scored two days later, Fig. 3B. The supplementation of Col-0 leaves with I3M, 1MO-I3M, and 4MO-I3M did not affect mite feeding and fecundity, indicating that levels of indole glucosinolates in Col-0 are sufficient to ensure maximal defenses (Fig. 3B). On the contrary, mites deposited significantly fewer feces and eggs on cyp79b2 cyp79b3 leaves supplemented with either I3M, 1MO-I3M, or 4MO-I3M relative to cyp79b2 cyp79b3 control leaves kept in water. Of the three indole glucosinolates, supplementation of cyp79b2 cyp79b3 leaves with I3M 
and $1 \mathrm{MO}-\mathrm{I} 3 \mathrm{M}$ reduced the number of feces and eggs to levels seen in Col-0, thus, fully restoring defenses in cyp79b2 cyp79b3 leaves, Fig. 3B. Mites feeding on 4MO-I3M treated cyp79b2 cyp79b3 leaves deposited $29 \%$ and $26 \%$ more feces and eggs respectively relative to Col-0. These results demonstrate that $\mathrm{I} 3 \mathrm{M}$ and $1 \mathrm{MO}-\mathrm{I} 3 \mathrm{M}$, and to a slightly lesser extent 4MO-I3M, can curtail mite feeding and oviposition on Arabidopsis leaves.

\section{Intact I3M, 1MO-I3M, and 4MO-I3M do not affect mite fitness}

$\mathrm{I} 3 \mathrm{M}, 1 \mathrm{MO}-\mathrm{I} 3 \mathrm{M}$ and 4MO-I3M glucosinolates require further modifications for antigut (Beran et al., 2014) myrosinase, or by the spontaneous breakdown in the gut (Kim and Jander 2007). To discriminate the mode of glucosinolate activation in the Arabidopsis - T. urticae interaction, we first tested if unmodified glucosinolate compounds affect mite fitness. We fed mites with $0.23,2.3$, or $4.6 \mathrm{mM} \mathrm{I3M}$ solutions for $19 \mathrm{~h}$, after which we transferred them to bean leaves for fecundity measurements at 24 and 48 hours, Fig. 4A. Direct delivery of I3M did not affect mite fitness and resulted in similar mite fecundity in treated and control mites (Fig. 4A). To test if continuity of mite exposure to intact indole glucosinolates is required for their effectiveness and to mimic their normal intake through ingestion, we supplemented bean leaf disks with water, I3M, $1 \mathrm{MO}-\mathrm{I} 3 \mathrm{M}$, or $4 \mathrm{MO}-\mathrm{I} 3 \mathrm{M}$ and subsequently examined mite feeding and oviposition over 24 h, Fig. 4B. I3M, 1MO-I3M, or 4MO-I3M extracted from treated bean leaves were stable throughout the experiment, indicating that mites were continuously exposed to constant and high levels of these metabolites, Supplemental Fig. S2. Mites deposited similar numbers of feces and eggs on treated and control bean leaf disks (Fig. 4B), demonstrating that infiltrated indole glucosinolates into bean leaves were ineffective against mites. Overall, these data indicate that I3M, 1MO-I3M, or 4MO-I3M cannot be activated by bean beta-glucosidases or in the mite gut. We therefore considered whether

Classical myrosinases TGG1 and TGG2 are required for indole glucosinolate activity

260 Classical myrosinases TGG1 and TGG2 are the main Arabidopsis enzymes catalyzing glucosinolate hydrolysis (Barth and Jander 2006). To test the requirement of TGG1 and TGG2 for Arabidopsis defenses against mite herbivory, we compared mite fitness parameters upon their feeding on tgg1 tgg 2 mutant plants relative to Col-0. Mites laid $28 \%$ more eggs on tggl tgg2 than on the Col-0 plants (Fig. 5A), caused $89 \%$ greater damage (Fig. 5B), required less time to progress through the larval developmental stage (from 5.2 to 4.5 days, Fig. 5C), and had 39\% lower larval mortality (Fig. 5D) in the 
267 absence of TGG1 and TGG2 activity, firmly supporting the requirement of TGG1 and 268 TGG2 for the establishment of Arabidopsis defenses. If TGG1 and TGG2 were the only 269 factors required for the activation of indole glucosinolates, then the loss of their activity 270 is expected to have the same impact on plant defenses as a loss of indole glucosinolate 271 biosynthesis in cyp79b2 cyp79b3 plants. However, mites caused $30 \%$ greater damage on 272 cyp79b2 cyp79b3 than on tgg1 tgg2 mutant plants (Fig. 5B), further accelerated their 273 development from 4.5 to 3.3 days (Fig. 5C), and reduced larval mortality by an additional $27425 \%$ (Fig. 5D). On cyp79b2 cyp79b3 relative to Col-0 leaves, mites caused $157 \%$ greater 275 damage and larvae mortality was reduced by $82.5 \%$. Therefore, TGG1 and TGG2 276 contribute to $\sim 50 \%$ of indole glucosinolate activity, suggesting the existence of additional 277 factors that are required for the establishment of indole glucosinolate defenses. We tested 278 the requirement of PEN2, an atypical myrosinase shown to metabolize IGs (Bednarek et 279 al., 2009), however, loss of its function in the pen2-1 mutant did not affect mite 280 fecundity, Fig. 5E.

\section{The indole glucosinolates are part of the wider MYC2/MYC3/MYC4-regulated} defenses against mites

The myc2 myc3 myc4 mutant plants lack a wide range of JA-regulated Arabidopsis responses including indole glucosinolates (Schweizer et al., 2013). To investigate the relative contribution of indole glucosinolates to JA-regulated defenses against mites, we compared mite fecundity when they fed on myc2 myc3 myc4 (that lack JA-regulated defenses), cyp79b2 cyp79b3 (that lack indole glucosinolate defenses), and fully defended Col-0 plants. Mite fecundity was five- and two-fold higher on myc2 myc3 myc4 and cyp79b2 cyp79b3, respectively, relative to Col-0 (Fig. 6A), establishing the existence of a wider array of JA-regulated Arabidopsis defenses against mite herbivory that are mediated through MYC2/MYC3/MYC4 signaling. To directly test the contribution of indole glucosinolates to MYC2/MYC3/MYC4-regulated defenses, we supplemented myc2 myc3 myc4 with I3M. Infiltration of I3M restored I3M and 4MO-I3M to levels measured in mite-infested Col-0 leaves kept in water (Figure 6B). However, 1MO-I3M was undetectable, demonstrating that $1 \mathrm{MO}-\mathrm{I} 3 \mathrm{M}$ formation upon mite feeding fully depends on MYC2/MYC3/MYC4 transcription factors. Mite oviposition decreased by $\sim 35 \%$ and $42 \%$ when fed on myc 2 myc3 myc4 leaves supplemented with I3M or 1MOI3M compared to myc2 myc3 myc4 untreated leaves (Fig. 6C and Supplemental Fig. S3), indicating that indole glucosinolates are prominent Arabidopsis defensive compounds against mite feeding. However, I3M and 1MO-I3M only partially complemented defenses in myc2 myc3 myc4, confirming the existence of additional, indole glucosinolate-independent, defensive compounds that restrict T. urticae herbivory. 


\section{DISCUSSION}

306 Camalexin, cyanogenic 4-OH-ICN metabolite, and indole glucosinolates are three classes of known tryptophan-derived defense metabolites. Among them, camalexin and 4-OHICN, produced through CYP71A12 and CYP71A13, were shown to act as specialized defense compounds against aphids and a variety of plant pathogens (Thomma et al., 1999; Bohman et al., 2004; Ferrari et al., 2007; Sanchez-Vallet et al., 2010; Schlaeppi et al., 2010; Kettles et al., 2013; Glindemann et al., 2019; Pastorczyk et al., 2020). Here, we demonstrated that defense compounds synthesized through CYP71A12- and CYP71A13dependent pathways are not protecting Arabidopsis from mite herbivory, Fig. 2A, even though levels of camalexin increase upon mite feeding (Zhurov et al., 2014). Instead, we showed that I3M, a parental metabolite of the indole glucosinolate pathway, can fully restore Trp-derived defenses controlling mite herbivory in otherwise defenseless cyp $79 \mathrm{~b} 2$ cyp79b3 plants, Fig. 2C. We further established that exogenously supplied I3M is converted into $1 \mathrm{MO}-\mathrm{I} 3 \mathrm{M}$ and $4 \mathrm{MO}-\mathrm{I} 3 \mathrm{M}$ indole glucosinolates in leaf tissues, and that all three metabolites act redundantly to control mite infestation, Fig. 3.

Upon mite feeding, both endogenous and exogenously supplied I3M are preferentially converted to $1 \mathrm{MO}-\mathrm{I} 3 \mathrm{M}$ rather than to $4 \mathrm{MO}-\mathrm{I} 3 \mathrm{M}$, Fig. 3. This favors Arabidopsis defenses against mites, as 1MO-I3M had greater suppressant effects on mites than 4MO-I3M (Fig. 3A). In contrast, in response to Myzus persicae feeding, I3M is exclusively modified to produce aphid-deterrent 4MO-I3M (Kim and Jander 2007). The control of metabolic fluxes within the indole glucosinolate biosynthetic pathway is achieved through transcriptional regulation of specific CYP81F enzymes and IG methyltransferases (IGMTs) (Winter et al., 2007; Pfalz et al., 2016). Conversion of I3M into $1 \mathrm{MO}-\mathrm{I} 3 \mathrm{M}$ and $4 \mathrm{MO}-\mathrm{I} 3 \mathrm{M}$ is carried out by complementary CYP81F and IGMT enzymes (Pfalz et al., 2016). Consistent with the dependence of 1MO-I3M synthesis on the MYC2/MYC3/MYC4, Fig. 6, the expression of CYP81F4 and IGMT5 that are required for the conversion of I3M into $1 \mathrm{MO}-\mathrm{I} 3 \mathrm{M}$ is JA-dependent (Winter et al., 2007; Schweizer et al., 2013; Sun et al., 2013). As mite feeding induces the accumulation of JA, whose effects are mediated by MYC2/MYC3/MYC4, it follows that mites also induce the synthesis of $1 \mathrm{MO}-\mathrm{I} 3 \mathrm{M}$. In contrast, in response to $M$. persicae herbivory, Arabidopsis plants do not accumulate JA and the expression of indole glucosinolate biosynthetic genes is suppressed (De Vos et al., 2005; Giordanengo et al., 2010; Sun et al., 2013; Appel et al., 2014; Foyer et al., 2015). Consequently, aphid feeding does not trigger the accumulation of $1 \mathrm{MO}-\mathrm{I} 3 \mathrm{M}$.

During vegetative development, Arabidopsis plants synthesize indole glucosinolates in both root and leaf tissues and can bidirectionally transport them between these organs (Andersen et al., 2013). Upregulation of indole glucosinolate biosynthetic genes in leaves in response to mite feeding indicates that at least a portion of defensive glucosinolates is synthesized in leaves (Zhurov et al., 2014). The vasculature has been proposed to facilitate indole glucosinolate long-distance transport, even though 
transporters that enable movement of indole glucosinolates between vasculature and the apoplast are currently unknown (Andersen et al., 2013). The complete restoration of defenses in cyp79b2 cyp79b3 leaves that were being supplemented with I3M through the petiole, expected to be taken up through the xylem, Fig. 2 and 3, demonstrates that leafimported I3M can defend leaf tissues against mites. Importantly, the infiltrated I3M must have been taken-up by cells, as it was converted into 1MO-I3M and 4MO-I3M by intracellular CYP81F and IGMT enzymes, Fig. 3. Endogenous I3M is synthesized in leaves by CYP83B1 localized in specialized cells that are adjacent to the phloem (Nintemann et al., 2018) and is stored in vasculature-associated S-cells (Koroleva et al., 2010). It is further distributed throughout the leaf blade with higher accumulation in the abaxial epidermal cells (Madsen et al., 2014). Whether this pattern of indole glucosinolate accumulation changes in response to mite feeding is currently unknown, however, its broad distribution is likely preserved.

Intact glucosinolates are not toxic and require modifications for their defensive activity. TGG1 and TGG2 are major Arabidopsis myrosinases that cleave thioglucoside bonds within the glucosinolate molecules, releasing highly reactive aglucones that are further modified to yield defensive compounds (Rask et al., 2000; Wittstock and Halkier 2002; Barth and Jander 2006; Kissen et al., 2009). High levels of TGG1 and TGG2 accumulate in guard cells in epidermal (Zhao et al., 2008), and in myrosin cells that are localized in the vicinity but in non-overlapping cells relative to glucosinolate synthesizing and storing cells, in phloem parenchyma (Husebye et al., 2002; Kissen et al., 2009; Li and Sack 2014; Shirakawa et al., 2014; Burow and Halkier 2017). The physical separation between glucosinolate- and myrosinase-storing cells led to a hypothesis that tissue maceration is required to enable their interaction and the generation of glucosinolate breakdown products. Consistent with this model and the requirement of TGG1 and TGG2 for the activation of aliphatic glucosinolates, Arabidopsis defenses against generalist chewing herbivores like Manduca sexta and Trichoplusia ni (Müller et al., 2010), are dependent on the activity of TGG1 and TGG2 (Barth and Jander 2006). However, the fitness of the Hemiptera Myzus persicae and Brevicoryne brassicae that are sensitive to indole glucosinolates is not affected by these myrosinases (Barth and Jander 2006). It has been postulated that aphid feeding, involving intercellular movement of the stylet before it reaches the phloem sieve elements (Tjallingii and Hogen Esch 1993), avoids rupturing of the myrosinase containing cells and thus prevents contact between TGG1 and TGG2 and glucosinolates (Kim et al., 2008). However, IGs are broken down post-ingestion in the aphid gut where they form conjugates that restrict aphid herbivory (Kim and Jander 2007). Whether the aphid gut contains enzymes with myrosinase activity, like Phyllotreta striolata (flea beetle) (Beran et al., 2014), or indole glucosinolates undergo spontaneous breakdown is at present unknown. Similar to aphids, mites use stylets to feed from individual mesophyll parenchyma cells (Bensoussan et al., 2016). Intact indole glucosinolates did not affect mite fitness (Fig. 4), indicating that the 
T. urticae gut lacks myrosinase activity and does not destabilize these metabolites. Instead, we found that the Arabidopsis myrosinases TGG1 and TGG2 are required to limit mite proliferation (Fig. 5). This is surprising, as mites, like aphids, are not expected to feed from the myrosinase-containing cells in phloem parenchyma. Whether mites sample some of the cellular content of guard cells as they sometimes protrude their stylets through a stomatal opening, and thus ingest some of the TGGs, is not known. In that case, the well-known "mustard oil bomb" system could be reconstituted in the mite gut. Alternatively, TGG myrosinases could be expressed in mesophyll parenchyma cells at a low level and thus may have evaded detection by in situs, promoter fusions, and antibody stainings (Xue et al., 1995; Husebye et al., 2002; Barth and Jander 2006; Kissen et al., 2009; Shirakawa and Hara-Nishimura 2018). This scenario could enable the activation of the "mustard oil bomb" within a single cell that mites consume. Alternatively, the effect of TGG1 and TGG2 may be indirect through the modification of the morphological and chemical properties of pavement and stomatal cells (Ahuja et al., 2016) that may hinder stylet penetration through the epidermis.

Mite fitness was greater on cyp79b2 cyp79b3 than on tgg1 tgg2 mutant plants (Fig. 5), which indicates the involvement of additional Arabidopsis factors in the generation of indole glucosinolate-dependent defensive compounds. For example, several other enzymes were shown to process indole glucosinolates (Bednarek et al., 2009; Clay et al., 2009; Nakano et al., 2017). One of them, PEN2 is required for Arabidopsis defenses against several pathogens (Lipka et al., 2005; Bednarek et al., 2009; Clay et al., 2009), but is dispensable for restricting mite fitness, Fig. 5E. PYK10 and BGLU18 are additional beta-glucosidases capable of hydrolyzing I3M and 4MO-I3M (Nakazaki et al., 2019; Sugiyama and Hirai 2019). Whether they are required for the Arabidopsis defenses against mites is currently not known. Regardless, Arabidopsis factors required for the generation of indole glucosinolate-dependent defensive compounds that act downstream of IG biosynthesis appear to be limiting plant defense against mites, as the excess of I3M, $1 \mathrm{MO}-\mathrm{I} 3 \mathrm{M}$ and 4MO-I3M in IG-supplemented Col-0 leaves did not increase Arabidopsis defenses against mites (Fig. 2 and 3). The processing of I3M, 1MO-I3M, and 4MO-I3M is expected to yield multiple active compounds that may affect mites directly or may induce the production of other defense compounds (Bednarek et al., 2009; Clay et al., 2009; Matern et al., 2019). In addition to IG-derived defense compounds, Arabidopsis plants likely have additional phytochemicals capable of restricting mite herbivory. They are dependent on MYC2/MYC3/MYC4 but are synthesized independently of array of chemical defenses against $T$. urticae herbivory.

\section{Conclusions}


424 The cyp79b2 cyp79b3 mutant plants lack Trp-derived metabolites and are more sensitive 425 to $T$. urticae. Here, we demonstrated that the Trp-derived metabolites synthesized 426 through the indole glucosinolate pathway are efficient against mites. Three indole 427 glucosinolates, I3M, 1MO-I3M, and 4MO-I3M, are able to complement the cyp79b2 428 cyp79b3 mutant leaves and restore feeding suppressant defenses against mites. Intact 429 indole glucosinolates are ineffective against mites. They require TGG1, TGG2 and other, 430 at present unknown, myrosinases to restrain mite proliferation. Indole glucosinolates are 431 part of the wider MYC2/MYC3/MYC4-regulated defenses against mites, indicating the 432 complexity of Arabidopsis defenses against T. urticae herbivory.

\section{MATERIALS AND METHODS}

\section{Plant materials and growth conditions}

436 The Arabidopsis thaliana wild-type seeds were obtained from the Arabidopsis Biological 437 Resource Center for Columbia-0 (Col-0) and H. Ghareeb (Göttingen University) for 438 Col-3 gl1. The seeds of myc2 myc3 myc4 were kindly provided by R. Solano 439 (Universidad Autónoma de Madrid), cyp79b2 cyp79b3 by B. A. Halkier (University of 440 Copenhagen), cyp7la12, cyp7la13 and cyp7la12 cyp7la13 by E. Glawischnig 441 (Technical University of Munich), pen2-1 by H. Ghareeb (Göttingen University), and $442 \operatorname{tgg} 1 \operatorname{tgg} 2$ by G. Jander (Cornell University). All Arabidopsis mutants are in the Col-0 443 background, except pen2-1 which is in the Col-3 gl1 background. Plants were grown at $44421-22^{\circ} \mathrm{C}$, with $50 \%$ relative humidity and a short-day $(10 \mathrm{~h}$ day/14 $\mathrm{h}$ night $)$ photoperiod. 445 All Arabidopsis plants used for experiments were 4 to 5-week-old. Bean plants 446 (Phaseolus vulgaris cultivar 'California Red Kidney'; Stokes, Thorold, ON) were grown 447 at $24^{\circ} \mathrm{C}, 55 \%$ relative humidity, and with a long-day ( $16 \mathrm{~h}$ day $/ 8 \mathrm{~h}$ night) photoperiod. 448 All bean plants used for experiments as well as the maintenance of the spider mite 449 population were 2 -week-old.

\section{Spider mite strain and rearing conditions}

451 The London reference Tetranychus urticae strain was reared on bean plants at $24^{\circ} \mathrm{C}, 55 \%$ 452 relative humidity, and long-day (16 h day/8 h night) photoperiod, as described previously 453 (Suzuki et al., 2017).

\section{Mite fecundity tests on detached Arabidopsis leaves}

455 The petiole of fully developed leaves was cut and submerged in $10 \mathrm{~mL}$ of water 456 contained in a small Petri plate covered with parafilm. Six hours later, each leaf was 457 infested with 10 adult female mites and the Petri plate was covered with a vented lid. The 458 total number of eggs deposited by 10 mites was recorded $48 \mathrm{~h}$ following mite infestation. 
459 All experiments were performed with at least five leaf replicates per genotype, which

460 were repeated in three independent trials with independent sets of plants.

\section{Choice experiment}

462 Fully-elongated adult leaves of Col-0 and cyp79b2 cyp79b3 were cut and each petiole 463 was inserted in a PCR tube containing water or $6 \%$ of blue food dye (erioglaucine; 464 McCormick, Sparks Glencoe, MD). After $6 \mathrm{~h}$, leaves were transferred and kept overnight 465 in a small Petri plate set-up described above. One blue-stained and one unstained leaf 466 were then placed into a vented box. 10 adult female spider mites were added to the box. 467 The number of blue feces and unstained feces was recorded $48 \mathrm{~h}$ after mite addition. Five 468 biological replicates/trial were performed in three independent trials, with independent 469 sets of plants.

\section{No-choice experiment}

471 Fully-elongated adult leaves were cut and petioles were inserted in a small Petri plate that 472 contained $10 \mathrm{~mL}$ of water and was covered with parafilm. Mites were retained within the 473 Petri dish with a vented lid. Twenty four hours later, leaves (labeled as "leaf 1") were 474 infested with 10 adult female mites. Eighteen hours following mite application, mites 475 were transferred to a new leaf ("leaf 2"). The numbers of eggs and feces were counted 24 $476 \mathrm{~h}$ following mite transfer to leaf 2. Experiments were performed in five biological 477 replicates/trial and three independent trials, with independent sets of plants.

\section{Fecundity assay on Arabidopsis leaves supplemented with IGs}

479 Fully developed leaves from five-week-old Col-0, cyp79b2 cyp79b3 or myc2 myc3 myc4 480 plants were detached and their petiole was inserted into a solution of I3M, 1MO-I3M, or $4814 \mathrm{MO}-\mathrm{I} 3 \mathrm{M}$, or water as a control. The 3-indolylmethyl glucosinolate or glucobrassicin 482 (I3M), the neoglucobrassicin (1MO-I3M), and the 4-methoxyglucobrassicin (4MO-I3M) 483 potassium salts were purchased from Extrasynthese (France), with the catalog numbers $4842525,2519 \mathrm{~S}$, and $2522 \mathrm{~S}$, respectively. Depending on the experiment, leaves were 485 treated for either $6 \mathrm{~h}$ with $2.4 \mathrm{mM}$ glucosinolate solution and then kept in water overnight 486 before mite infestation, or for $24 \mathrm{~h}$ with $4.8 \mathrm{mM}$ glucosinolate solution and were then 487 transferred into the water for immediate mite infestation. After treatment, each leaf 488 (inserted in a small Petri plate covered with parafilm and containing $10 \mathrm{~mL}$ of water) was 489 infested with ten adult female mites, which were retained within the plate with a vented 490 lid. The number of eggs and feces was counted $48 \mathrm{~h}$ following mite leaf infestation. For 491 each condition of compound supplementation, five biological replicates/trial were 492 performed in three to four independent trials, with independent sets of plants.

\section{Fecundity assay on bean leaf disks supplemented with IGs}


494 We followed protocol described by Ghazy et al. to deliver IGs to bean leaves (Ghazy et 495 al., 2020). Briefly, bean leaf disks, $1.2 \mathrm{~cm}$ in diameter, were excised with a hole puncher 496 from the first pair of leaves of 2-week-old bean plants. A 9.6 $\mu \mathrm{L}$ volume of I3M, 1MO$497 \mathrm{I} 3 \mathrm{M}$, or $4 \mathrm{MO}-\mathrm{I} 3 \mathrm{M}$ solution at $4.6 \mathrm{mM}$, or of water as a control, was spread on the adaxial 498 side of each disk. The disks were immediately covered with parafilm to avoid leaf 499 desiccation and $3 \mathrm{~h}$ later, 10 adult female mites were placed on the adaxial side of each 500 disk, surrounded by wet Kimwipe strips (Kimberly-Clark Professional Kimtech Science 501 Kimwipes) to prevent mite escape. The number of eggs and feces was recorded $24 \mathrm{~h}$ after 502 mite addition to the disks. For each compound, five leaf disks were used in each of three 503 independent trials, with independent sets of plants.

\section{Direct application of IGs to mites}

The 3-indolylmethyl glucosinolate (I3M) was applied directly to mites following protocol described in Suzuki et al., 2017. Briefly, a piece of 5 x 5 mm Kimwipes (Kimberly-Clark Professional Kimtech Science Kimwipes) was soaked with $10 \mu \mathrm{L}$ of I3M solution applied at $0.23 \mathrm{mM}, 2.3 \mathrm{mM}$, or $4.6 \mathrm{mM}$, or with $10 \mu \mathrm{L}$ water as a control, and was kept in a sealed Petri plate for $19 \mathrm{~h}$ at $20^{\circ} \mathrm{C}$. Subsequently, mites were transferred to bean leaf squares laid on a wet filter paper. Fecundity was assessed $24 \mathrm{~h}$ and $48 \mathrm{~h}$ after mite transfer. One biological replicate comprised one bean leaf square with 10 mites. For each concentration, three biological replicates/trial were performed in three independent trials, with independent sets of plants.

This method of delivery was validated chemically with a coumarin solution (10 $\mathrm{mM})$ and its control solution (10\% methanol), Supplemental Fig. S4. Following coumarin treatment, mite mortality was assessed $2 \mathrm{~h}$ after transfer on a bean leaf. One biological replicate comprised one bean leaf with $\sim 30$ mites. Three biological replicates/trial were performed in three independent trials, with independent sets of plants.

520 Ten adult female mites were placed on Col-0, tgg1 tgg2 and cyp79b2 cyp79b3 plants. Three days later, the entire rosettes were cut from the roots and scanned using a Canon CanoScan $8600 \mathrm{~F}$ model scanner at a resolution of 1200 dpi and a brightness setting of +25. Pictures were saved as .jpg files and damage quantification was subsequently performed with Adobe Photoshop 5 (Adobe Systems, San Jose, CA) as described previously (Cazaux et al., 2014). Ten plants per genotype were used per trial. The

526 experiment was performed in three independent trials with independent sets of plants.

528 Fully-elongated adult leaves of Col-0, tgg1 tgg2 and cyp79b2 cyp79b3 were cut and each 529 petiole was inserted in a small Petri plate containing $10 \mathrm{~mL}$ of water covered with 530 parafilm. Subsequently, 25 newly molted larvae were placed on each leaf and a vented lid 
531 was fixed to prevent mite escape. On each day following infestation, the number of

532 larvae, their viability and molting were recorded. The average number of days required

533 for 25 larvae to develop into protonymphs on each detached leaf was used as the data

534 point. Leaves were replaced every other day (day 0, 2, 4, etc.) until all larvae either

535 molted into protonymphs or died. Protonymphs were removed when counted. Five leaves

536 per genotype were infested per trial and the experiment was repeated in three independent

537 trials.

\section{Indole glucosinolate analysis by HPLC-MS}

539 Metabolites were extracted from frozen leaves in a methanol $70 \%$ buffer containing the 540 allylglucosinolate sinigrin $(80 \mu \mathrm{g} / \mathrm{mL},(-)$-Sinigrin hydrate, Sigma-Aldrich) as an internal 541 standard, with a fresh weight/buffer volume ratio of $100 \mathrm{mg} / \mathrm{mL}$. After grinding the 542 biological sample in the buffer manually with a pestle, metabolites were further extracted 543 by vortexing $(1 \mathrm{~min})$ and then by sonication $(10 \mathrm{~min})$. Debris was removed by two 544 successive centrifugations at $16160 \mathrm{~g}$ and the supernatant was analyzed by high545 performance liquid chromatography coupled with a time-of-flight mass spectrometry 546 (LC/ TOF MS) using an Agilent 1260 Infinity LC system coupled to an Agilent 6230 547 TOF system. The Zorbax Eclipse Plus C-18 column Rapid Resolution HT (3 X 100 mm, $5481.8 \mu \mathrm{m}, 600 \mathrm{bar}$, Agilent, USA) was kept at $25^{\circ} \mathrm{C}$ and the elution was performed with 549 acetonitrile (Optima, Fisher chemical, UK) and water containing formic acid (Sigma550 Aldrich, Germany). A gradient of solvent $\mathrm{A}\left(\mathrm{H}_{2} \mathrm{O}\right.$ containing $0.1 \%$ formic acid) and 551 solvent $\mathrm{B}\left(\mathrm{CH}_{3} \mathrm{CN} 90 \%\right.$ in $\mathrm{H}_{2} \mathrm{O}$, containing $0.1 \%$ formic acid) was applied as follows. 552 The initial condition was $5 \% \mathrm{~B}$ in A, which was held for 2 minutes, with the first minute 553 of eluent sent to waste. Metabolites were eluted with a linear gradient to $100 \%$ B over 20 554 minutes. After a 5 minute wash at $100 \%$ B, initial conditions of $5 \%$ B in A were 555 established over 1 minute followed by a 4 min post run at initial conditions before the 556 next injection. The injection volume was $10 \mu \mathrm{L}$ for each sample. The flow rate was set to $5570.4 \mathrm{~mL} / \mathrm{min}$ and infused into an Agilent 6230 TOF MS through a Dual Spray ESI source 558 with a gas temperature of $325^{\circ} \mathrm{C}$ flowing at $8 \mathrm{~L} / \mathrm{min}$, and a nebulizer pressure of 35 psi. 559 The fragmentor voltage was set to $175 \mathrm{~V}$ with a capillary voltage of $3500 \mathrm{~V}$ and a 560 skimmer voltage of $65 \mathrm{~V}$. The instrument was set in negative ESI mode. The negative-ion 561 full-scan mass spectra were recorded over a 85 to $1200 \mathrm{~m} / \mathrm{z}$ range. The MassHunter 562 Workstation Software Qualitative analysis Version B.05.00 (Agilent Technologies, Inc. 563 2011) was used for visualizing the chromatograms and peak integration. The compounds 564 of interest were detected by the following ions $[\mathrm{M}-\mathrm{H}]^{-}$(theoretical mass, actual mass 565 found) at specific retention times (RT): sinigrin, m/z 358.0272, 358.0314 (RT $1.8 \mathrm{~min}$ ); $566 \mathrm{I}$ I3M, m/z 447.0537, 447.0547 (RT $6.8 \mathrm{~min}$ ); 4MO-I3M m/z 477.0643, 477.0675 (RT 7.8 $567 \mathrm{~min}$ ) and $1 \mathrm{MO}-\mathrm{I} 3 \mathrm{M}, \mathrm{m} / \mathrm{z} 477.0643,477.0663$ (RT $8.8 \mathrm{~min}$ ). The relative quantification 568 of each metabolite was obtained by correcting the peak area with that of the recovery of 569 the internal standard sinigrin, and is expressed in area units (a.u.). The absolute amount of 
570 each IG in plant extracts was further calculated based on standard ranges of synthetic $571 \mathrm{I} 3 \mathrm{M}, 4 \mathrm{MO}-\mathrm{I} 3 \mathrm{M}$, and 1MO-I3M and the tissue weight, and expressed in $\mathrm{nmol} / \mathrm{g}$ of fresh 572 weight (F.W.) .

\section{Statistical analysis}

574 Statistical analysis was performed using $\mathrm{R}$ software ( $\mathrm{R}$ Core Team, 2014). For the 575 fecundity tests on Arabidopsis mutant leaves, the no-choice experiment, the fecundity 576 assay on bean leaves supplemented with I3M, the direct application of IGs to mites, and 577 the metabolic analysis of IG solutions used for experiments, we used a two-way ANOVA 578 testing for the main effects of trial, genotype, and any interaction. Interaction terms 579 including trial were included in all statistical analyses to test for reproducibility between 580 trials (Brady et al., 2015). A Tukey's honestly significant difference (HSD) test was performed following the ANOVA to determine differences between genotypes or between treatments. For the fecundity assays on Arabidopsis leaves supplemented with IGs, count data were analyzed by two-way ANOVA with the interaction of plant genotype and supplemented compound used as the first explanatory variable and trial as the second. No significant effect of the experimental trial was detected, and ANOVA was followed by Tukey's HSD test. For the two-choice experiment with Col-0 and cyp79b2 cyp79b3 leaves, after establishing homogeneity of response, count data from individual trials were pooled for the final analysis using goodness-of-fit G-test using $\mathrm{R}$ package DescTools ( $\mathrm{R}$ Core Team, 2014) to assess the statistical significance of feces color deviation from a 1:1 ratio of non-colored:blue feces. For the metabolic analysis of leaves from Arabidopsis and bean supplemented with IGs, and the fecundity assays on Col-0, cyp79b2 cyp79b3, and myc2 myc3 myc4 leaves supplemented with I3M, a three-way ANOVA was performed testing for the main effects of trial, genotype, and treatment. A lack of significant interactions ( 2 and 3-way) with the other main effects of genotype and treatment signified the data could be combined across trials. The linear model was then simplified by excluding non-relevant, non-significant interactions leaving the 3 main effects and the biologically relevant interaction term between genotype and treatment only. Another three-way ANOVA was performed using the simplified linear model. Differences between genotypes and treatment were determined with a Tukey's HSD test. The mortality experiment involving coumarin was analysed using a two-way ANOVA testing for the main effects of treatment and trial and any interaction between the two variables. Post-hoc analysis was not required as there were only two treatments to be compared. For the developmental and mortality assays using the tgg 1 tgg 2 Arabidopsis mutant, two-way ANOVAs testing for the main effects of trial, genotype, and any interaction between the two variables was used. A Tukey's honestly significant difference (HSD) test was performed following the ANOVA to determine differences in pairwise comparisons between genotypes. 


\section{Acknowledgments}

610 The authors thank an undergraduate student Emma Somerville for her help with 611 experiments.

\section{$613 \quad$ Figure legends}

614 Figure 1. Trp-derived metabolites suppress mite feeding and fecundity. A, 615 Experimental set-up for the mite feeding experiment where mites were given the choice 616 to feed on Col-0 or cyp79b2 cyp79b3 (cyp79b2b3) leaves. To track leaves mites fed on, 617 one leaf was supplemented with blue dye and the other remained unstained. Mites 618 feeding on the blue leaf produced blue feces. B, The total number of blue and non-stained 619 feces excreted by 10 mites after $48 \mathrm{~h}$. Asterisks indicate a deviation from a 1:1 ratio of 620 non-colored:blue feces $(\mathrm{p} \leq 0.05)$. C, The effectiveness of Trp-derived metabolites upon mite transfer between Col-0 and cyp79b2 cyp79b3 (cyp79b2b3) leaves. Ten mites were added to the first leaf and $18 \mathrm{~h}$ later, they were transferred to the second leaf. The total number of feces and eggs was scored on the second leaf $24 \mathrm{~h}$ after transfer. Significant differences $(\mathrm{p} \leq 0.05)$ are indicated by different letters. (B-C) Experiments were performed in five biological replicates/trial and in three independent trials. Data represent the mean \pm SE of three trials.

Figure 2. The contribution of individual Trp-derived metabolic pathways to Arabidopsis defenses against mites. A, Spider mite fecundity upon feeding on Col-0, cyp79b2 cyp79b3 (cyp79b2b3), cyp71a12, cyp71a13 and cyp71a12 cyp71a13 (cyp7la12a13) leaves. The total number of eggs per leaf was recorded $48 \mathrm{~h}$ after the addition of 10 mites/leaf. B, Levels of I3M in Col-0 and cyp79b2 cyp79b3 (cyp79b2b3) leaves supplemented with I3M and infested with 10 mites. (+I3M), leaves supplemented with solution of $2.4 \mathrm{mM} \mathrm{I3M}$ for $6 \mathrm{~h}$ and kept in water for $16 \mathrm{~h}$ before mite addition; (+ mite), leaves challenged with 10 mites for $48 \mathrm{~h}$; (-I3M/- mite), untreated leaves immediately frozen after being cut from intact plant. C, The effect of I3M supplementation to Col-0 and cyp79b2 cyp79b3 (cyp79b2b3) leaves on total number of eggs laid by 10 mites $48 \mathrm{~h}$ after the infestation. A-C, Experiments were performed in at least five biological replicates/trial and in three independent trials. Data represent the mean \pm SE of three trials. Significant differences $(p \leq 0.05)$ are indicated by different letters.

Figure 3. Supplementation with I3M, 1MO-I3M or 4MO-I3M indole glucosinolates fully restores defenses in cyp79b2 cyp79b3 leaves. A, Levels of I3M, 1MO-I3M, and 4MO-I3M in Col-0 and cyp79b2 cyp79b3 (cyp79b2b3) leaves supplemented with IGs. 645 (+mite), leaves challenged with mites for 48h. Values were $\log 2$ transformed for 
646 statistical analysis. B, Mite fitness upon feeding on Col-0 and cyp79b2 cyp79b3 647 (cyp79b2b3) leaves supplemented with I3M, 1MO-I3M or 4MO-I3M. The total numbers 648 of deposited feces (top panels) and eggs (bottom panels) were recorded $48 \mathrm{~h}$ after the 649 addition of 10 mites per leaf. Experiments were performed in five biological 650 replicates/trial and in four independent trials. Data represent the mean \pm SE of four trials. 651 Significant differences $(\mathrm{p} \leq 0.05)$ are indicated by different letters.

652 Figure 4. Intact I3M, 1MO-I3M, and 4MO-I3M are not efficient against mites. A, 653 Mite fecundity upon direct application of $0.23,2.3$ or $4.6 \mathrm{mM} \mathrm{I3M}$ to mites. Mites were 654 treated for $19 \mathrm{~h}$ with I3M solutions and were subsequently transferred to bean leaves. 655 Mite fecundity was determined at 24 and $48 \mathrm{~h}$ after treatment. B, The total number of 656 deposited feces and eggs over $24 \mathrm{~h}$ of feeding on bean leaf disk treated with $2.4 \mathrm{mM}$ of 657 I3M, 1MO-I3M, or 4MO-I3M. Experiments were performed in three (in A) and five (in 658 B) biological replicates/trial and in three independent trials. Data represent the mean \pm SE 659 of three trials. Significant differences $(p \leq 0.05)$ are indicated by different letters.

660

Figure 5. The Arabidopsis myrosinases TGG1 and TGG2 are required for Arabidopsis defense against mites. A, Fecundity of 10 mites upon feeding on Col-0 and tgg 1 tgg2 leaves for $48 \mathrm{~h}$. B-D, Comparison of mite damage and fitness upon feeding on Col-0, tgg1 tgg2, and cyp79b2 cyp79b3 (cyp79b2b3) leaves. B, Leaf damage resulting from feeding of 10 mites per plant over three days. $\mathbf{C}$, Time required for larvae to become nymphs. D, Larval mortality. E, Fecundity of 10 mites upon feeding on Col-3 gl1 and pen2-1 leaves for $48 \mathrm{~h}$. Experiments were performed in five (in A, C-E) and ten (in B) biological replicates/trial and in three independent trials. Data represent the mean $\pm \mathrm{SE}$ of three trials. Significant differences $(p \leq 0.05)$ are indicated by different letters.

Figure 6. MYC2 MYC3 MYC4 are required for indole glucosinolate-mediated and Trp-independent defenses against mites in Arabidopsis. A, Fecundity of 10 mites feeding for $48 \mathrm{~h}$ on Col-0, myc2 myc3 myc4 (myc234) and cyp79b2 cyp79b3 (cyp79b2b3) leaves. B, Levels of I3M, 1MO-I3M and 4MO-I3M in Col-0 and myc2 myc3 myc4 (myc234) leaves supplemented with $2.4 \mathrm{mM} \mathrm{I3M}$ for $6 \mathrm{~h}$ and kept in water for $16 \mathrm{~h}$ before mite addition. (-I3M/-mite), untreated leaves were immediately frozen after being cut from intact plant; (+ mite) leaves challenged with mites for $48 \mathrm{~h}$. C, Fecundity of 10 mites upon feeding for $48 \mathrm{~h}$ on Col-0, cyp79b2 cyp79b3 (cyp79b2b3) and myc2 myc3 myc4 (myc234) leaves supplemented with $4.8 \mathrm{mM} \mathrm{I3M}$ or $1 \mathrm{MO}-\mathrm{I} 3 \mathrm{M}$ for $24 \mathrm{~h}$ before mite

681 independent trials. Data represent the mean \pm SE of three trials. Significant differences ( $p$ $682 \leq 0.05)$ are indicated by different letters.

683 Supplemental Figure S1. Mite fecundity upon feeding on cyp79b2 cyp79b3 leaves 684 supplemented with $4.8 \mathrm{mM}$ I3M over $24 \mathrm{~h}$. The total number of eggs per leaf was 
685 recorded $48 \mathrm{~h}$ after the addition of 10 mites/leaf. Experiment was performed in five 686 biological replicates/trial and in three independent trials. Data represent the mean \pm SE of 687 three trials. Significant differences $(\mathrm{p} \leq 0.05)$ are indicated by different letters.

688 Supplemental Figure S2. Stability of I3M, 1MO-I3M and 4MO-I3M in 689 supplemented bean leaf disks. T0, leaf disks collected immediately after application of 690 I3M, 1MO-I3M or 4MO-I3M; T51, leaf disks collected at the end of the experiment, $48 \mathrm{~h}$ 691 after mite infestation (51 h after IG application). Experiment was performed in three 692 biological replicates/trial and in three independent trials. Data represent the mean \pm SE of 693 three trials. Significant differences $(p \leq 0.05)$ are indicated by different letters.

694 Supplemental Figure S3. I3M supplementation partially rescues defenses in myc2 695 myc3 myc4 leaves. Mite fecundity upon feeding on Col-0, cyp79b2 cyp79b3 (cyp79b2b3) 696 and myc2 myc3 myc4 (myc234) leaves supplemented with $2.4 \mathrm{mM} \mathrm{I3M}$ for $6 \mathrm{~h}$ and kept 697 in water for $16 \mathrm{~h}$ before mite addition. The total number of eggs per leaf was recorded 48 $698 \mathrm{~h}$ after the addition of 10 mites/leaf. Experiment was performed in at least five biological 699 replicates/trial and in three independent trials. Data represent the mean \pm SE of three 700 trials. Significant differences $(p \leq 0.05)$ are indicated by different letters.

701 Supplemental Figure S4. Mite mortality after direct application of $10 \mathrm{mM}$ coumarin 702 solution to mites. Experiment was performed in three biological replicates/trial and in 703 three independent trials. Data represent the mean \pm SE of three trials. Significant 704 difference $(\mathrm{p} \leq 0.05)$ is indicated by an asterisk. 


\section{REFERENCES}

Ahuja I, de Vos RC, Rohloff J, Stoopen GM, Halle KK, Ahmad SJ, Hoang L, Hall RD, Bones AM (2016) Arabidopsis myrosinases link the glucosinolatemyrosinase system and the cuticle. Sci Rep 6: 38990.

Andersen TG, Nour-Eldin HH, Fuller VL, Olsen CE, Burow M, Halkier BA (2013) Integration of biosynthesis and long-distance transport establish organ-specific glucosinolate profiles in vegetative Arabidopsis. Plant Cell 25 (8): 3133-45.

Appel HM, Fescemyer H, Ehlting J, Weston D, Rehrig E, Joshi T, Xu D, Bohlmann J, Schultz J (2014) Transcriptional responses of Arabidopsis thaliana to chewing and sucking insect herbivores. Front Plant Sci 5: 565.

Barth C, Jander G (2006) Arabidopsis myrosinases TGG1 and TGG2 have redundant function in glucosinolate breakdown and insect defense. Plant J 46 (4): 549-62.

Bednarek P, Pislewska-Bednarek M, Svatos A, Schneider B, Doubsky J, Mansurova M, Humphry M, Consonni C, Panstruga R, Sanchez-Vallet A, et al (2009) A glucosinolate metabolism pathway in living plant cells mediates broad-spectrum antifungal defense. Science 323 (5910): 101-6.

Bensoussan N, Santamaria ME, Zhurov V, Diaz I, Grbić M, Grbić V (2016) PlantHerbivore Interaction: Dissection of the Cellular Pattern of Tetranychus urticae Feeding on the Host Plant. Front Plant Sci 7: 1105.

Beran F, Pauchet Y, Kunert G, Reichelt M, Wielsch N, Vogel H, Reinecke A, Svatoš A, Mewis I, Schmid D, et al (2014) Phyllotreta striolata flea beetles use host plant defense compounds to create their own glucosinolate-myrosinase system. Proc Natl Acad Sci U S A 111 (20): 7349-54.

Bhat R, Vyas D (2019) Myrosinase: insights on structural, catalytic, regulatory, and environmental interactions. Crit Rev Biotechnol 39 (4): 508-523.

Bjorkman R (1976) Properties and function of plant myrosinases. The Biology and Chemistry of the Cruciferae. J. G. Vaughan, A. J. Macleod \& B. M. G. Jones, eds 1976: 191-205.

Blažević I, Montaut S, Burčul F, Olsen CE, Burow M, Rollin P, Agerbirk N (2020) Glucosinolate structural diversity, identification, chemical synthesis and metabolism in plants. Phytochemistry 169: 112100.

Bohman S, Staal J, Thomma BP, Wang M, Dixelius C (2004) Characterisation of an Arabidopsis-Leptosphaeria maculans pathosystem: resistance partially requires camalexin biosynthesis and is independent of salicylic acid, ethylene and jasmonic acid signalling. Plant J 37 (1): 9-20.

Bones AM, Rossiter JT (2006) The enzymic and chemically induced decomposition of glucosinolates. Phytochemistry 67 (11): 1053-67.

Brady SM, Burow M, Busch W, Carlborg Ö, Denby KJ, Glazebrook J, Hamilton ES, Harmer SL, Haswell ES, Maloof JN, et al (2015) Reassess the t Test: Interact with All Your Data via ANOVA. Plant Cell 27 (8): 2088-94.

Brown PD, Tokuhisa JG, Reichelt M, Gershenzon J (2003) Variation of glucosinolate accumulation among different organs and developmental stages of Arabidopsis thaliana. Phytochemistry 62 (3): 471-81.

Burow M, Halkier BA (2017) How does a plant orchestrate defense in time and space? Using glucosinolates in Arabidopsis as case study. Curr Opin Plant Biol 38: 142147. 
Cazaux M, Navarro M, Bruinsma KA, Zhurov V, Negrave T, Van Leeuwen T, Grbic V, Grbic M (2014) Application of two-spotted spider mite Tetranychus urticae for plant-pest interaction studies. J Vis Exp (89).

Clay NK, Adio AM, Denoux C, Jander G, Ausubel FM (2009) Glucosinolate metabolites required for an Arabidopsis innate immune response. Science $\mathbf{3 2 3}$ (5910): 95-101.

De Vos M, Van Oosten VR, Van Poecke RM, Van Pelt JA, Pozo MJ, Mueller MJ, Buchala AJ, Métraux JP, Van Loon LC, Dicke M, et al (2005) Signal signature and transcriptome changes of Arabidopsis during pathogen and insect attack. Mol Plant Microbe Interact 18 (9): 923-37.

Fahey JW, Zalcmann AT, Talalay $\mathbf{P}$ (2001) The chemical diversity and distribution of glucosinolates and isothiocyanates among plants. Phytochemistry 56 (1): 5-51.

Ferrari S, Galletti R, Denoux C, De Lorenzo G, Ausubel FM, Dewdney J (2007) Resistance to Botrytis cinerea induced in Arabidopsis by elicitors is independent of salicylic acid, ethylene, or jasmonate signaling but requires PHYTOALEXIN DEFICIENT3. Plant Physiol 144 (1): 367-79.

Foyer CH, Verrall SR, Hancock RD (2015) Systematic analysis of phloem-feeding insect-induced transcriptional reprogramming in Arabidopsis highlights common features and reveals distinct responses to specialist and generalist insects. J Exp Bot 66 (2): 495-512.

Ghazy NA, Okamura M, Sai K, Yamakawa S, Hamdi FA, Grbic V, Suzuki T (2020) A Leaf-Mimicking Method for Oral Delivery of Bioactive Substances Into Sucking Arthropod Herbivores. Front Plant Sci 11: 1218.

Giordanengo P, Brunissen L, Rusterucci C, Vincent C, van Bel A, Dinant S, Girousse C, Faucher M, Bonnemain JL (2010) Compatible plant-aphid interactions: how aphids manipulate plant responses. C R Biol 333 (6-7): 516-23.

Glawischnig E (2007) Camalexin. Phytochemistry 68 (4): 401-6.

Glindemann CP, Backenköhler A, Strieker M, Wittstock U, Klahn P (2019) Synthesis and Biochemical Evaluation of an Artificial, Fluorescent Glucosinolate (GSL). Chembiochem 20 (18): 2341-2345.

Howe GA, Jander G (2008) Plant immunity to insect herbivores. Annu Rev Plant Biol 59: 41-66.

Husebye H, Chadchawan S, Winge P, Thangstad OP, Bones AM (2002) Guard celland phloem idioblast-specific expression of thioglucoside glucohydrolase 1 (myrosinase) in Arabidopsis. Plant Physiol 128 (4): 1180-8.

Jeschke V, Kearney EE, Schramm K, Kunert G, Shekhov A, Gershenzon J, Vassão DG (2017) How Glucosinolates Affect Generalist Lepidopteran Larvae: Growth, Development and Glucosinolate Metabolism. Front Plant Sci 8: 1995.

Kettles GJ, Drurey C, Schoonbeek HJ, Maule AJ, Hogenhout SA (2013) Resistance of Arabidopsis thaliana to the green peach aphid, Myzus persicae, involves camalexin and is regulated by microRNAs. New Phytol 198 (4): 1178-90.

Kim JH, Jander G (2007) Myzus persicae (green peach aphid) feeding on Arabidopsis induces the formation of a deterrent indole glucosinolate. Plant J 49 (6): 1008-19.

Kim JH, Lee BW, Schroeder FC, Jander G (2008) Identification of indole glucosinolate breakdown products with antifeedant effects on Myzus persicae (green peach aphid). Plant J 54 (6): 1015-26. 
Kissen R, Rossiter JT, Bones AM (2009) The 'mustard oil bomb': not so easy to assemble?! Localization, expression and distribution of the components of the myrosinase enzyme system. Phytochem Rev 8: 69-86.

Koroleva OA, Gibson TM, Cramer R, Stain C (2010) Glucosinolate-accumulating Scells in Arabidopsis leaves and flower stalks undergo programmed cell death at early stages of differentiation. Plant J 64 (3): 456-69.

Li M, Sack FD (2014) Myrosin idioblast cell fate and development are regulated by the Arabidopsis transcription factor FAMA, the auxin pathway, and vesicular trafficking. Plant Cell 26 (10): 4053-66.

Lipka V, Dittgen J, Bednarek P, Bhat R, Wiermer M, Stein M, Landtag J, Brandt W, Rosahl S, Scheel D, et al (2005) Pre- and postinvasion defenses both contribute to nonhost resistance in Arabidopsis. Science 310 (5751): 1180-3.

Lortzing T, Steppuhn A (2016) Jasmonate signalling in plants shapes plant-insect interaction ecology. Curr Opin Insect Sci 14: 32-39.

Madsen SR, Olsen CE, Nour-Eldin HH, Halkier BA (2014) Elucidating the role of transport processes in leaf glucosinolate distribution. Plant Physiol 166 (3): 145062.

Mahmut D (2020) Conflicting perceptions of education in Canada: the perspectives of well-educated Muslim Uyghur immigrants. Diaspora, Indigenous, and Minority Education: 1-13.

Matern A, Böttcher C, Eschen-Lippold L, Westermann B, Smolka U, Döll S, Trempel F, Aryal B, Scheel D, Geisler M, et al (2019) A substrate of the ABC transporter PEN3 stimulates bacterial flagellin (flg22)-induced callose deposition in Arabidopsis thaliana. J Biol Chem 294 (17): 6857-6870.

Meier K, Ehbrecht MD, Wittstock U (2019) Glucosinolate Content in Dormant and Germinating Arabidopsis thaliana Seeds Is Affected by Non-Functional Alleles of Classical Myrosinase and Nitrile-Specifier Protein Genes. Front Plant Sci 10: 1549.

Müller R, de Vos M, Sun JY, Sønderby IE, Halkier BA, Wittstock U, Jander G (2010) Differential effects of indole and aliphatic glucosinolates on lepidopteran herbivores. J Chem Ecol 36 (8): 905-13.

Nakano RT, Piślewska-Bednarek M, Yamada K, Edger PP, Miyahara M, Kondo M, Böttcher C, Mori M, Nishimura M, Schulze-Lefert P, et al (2017) PYK10 myrosinase reveals a functional coordination between endoplasmic reticulum bodies and glucosinolates in Arabidopsis thaliana. Plant J 89 (2): 204-220.

Nakazaki A, Yamada K, Kunieda T, Sugiyama R, Hirai MY, Tamura K, HaraNishimura I, Shimada T (2019) Leaf Endoplasmic Reticulum Bodies Identified in Arabidopsis Rosette Leaves Are Involved in Defense against Herbivory. Plant Physiol 179 (4): 1515-1524.

Nintemann SJ, Hunziker P, Andersen TG, Schulz A, Burow M, Halkier BA (2018) Localization of the glucosinolate biosynthetic enzymes reveals distinct spatial patterns for the biosynthesis of indole and aliphatic glucosinolates. Physiol Plant 163 (2): 138-154.

Pastorczyk M, Kosaka A, Pislewska-Bednarek M, Lopez G, Frerigmann H, Kulak K, Glawischnig E, Molina A, Takano Y, Bednarek P (2020) The role of 
CYP71A12 monooxygenase in pathogen-triggered tryptophan metabolism and Arabidopsis immunity. New Phytol 225 (1): 400-412.

Pfalz M, Mukhaimar M, Perreau F, Kirk J, Hansen CI, Olsen CE, Agerbirk N, Kroymann J (2016) Methyl Transfer in Glucosinolate Biosynthesis Mediated by Indole Glucosinolate O-Methyltransferase 5. Plant Physiol 172 (4): 2190-2203.

Rajniak J, Barco B, Clay NK, Sattely ES (2015) A new cyanogenic metabolite in Arabidopsis required for inducible pathogen defence. Nature 525 (7569): 376-9.

Rask L, Andréasson E, Ekbom B, Eriksson S, Pontoppidan B, Meijer J (2000) Myrosinase: gene family evolution and herbivore defense in Brassicaceae. Plant Mol Biol 42 (1): 93-113.

Sanchez-Vallet A, Ramos B, Bednarek P, López G, Piślewska-Bednarek M, SchulzeLefert P, Molina A (2010) Tryptophan-derived secondary metabolites in Arabidopsis thaliana confer non-host resistance to necrotrophic Plectosphaerella cucumerina fungi. Plant J 63 (1): 115-27.

Schlaeppi K, Abou-Mansour E, Buchala A, Mauch F (2010) Disease resistance of Arabidopsis to Phytophthora brassicae is established by the sequential action of indole glucosinolates and camalexin. Plant J 62 (5): 840-51.

Schweizer F, Fernández-Calvo P, Zander M, Diez-Diaz M, Fonseca S, Glauser G, Lewsey MG, Ecker JR, Solano R, Reymond P (2013) Arabidopsis basic helixloop-helix transcription factors MYC2, MYC3, and MYC4 regulate glucosinolate biosynthesis, insect performance, and feeding behavior. Plant Cell 25 (8): 3117 32.

Shirakawa M, Hara-Nishimura I (2018) Specialized Vacuoles of Myrosin Cells: Chemical Defense Strategy in Brassicales Plants. Plant Cell Physiol 59 (7): 13091316.

Shirakawa M, Ueda H, Nagano AJ, Shimada T, Kohchi T, Hara-Nishimura I (2014) FAMA is an essential component for the differentiation of two distinct cell types, myrosin cells and guard cells, in Arabidopsis. Plant Cell 26 (10): 4039-52.

Shroff R, Schramm K, Jeschke V, Nemes P, Vertes A, Gershenzon J, Svatos A (2015) Quantification of plant surface metabolites by matrix-assisted laser desorption-ionization mass spectrometry imaging: glucosinolates on Arabidopsis thaliana leaves. Plant J 81 (6): 961-72.

Sønderby IE, Burow M, Rowe HC, Kliebenstein DJ, Halkier BA (2010) A complex interplay of three R2R3 MYB transcription factors determines the profile of aliphatic glucosinolates in Arabidopsis. Plant Physiol 153 (1): 348-63.

Sugiyama R, Hirai MY (2019) Atypical Myrosinase as a Mediator of Glucosinolate Functions in Plants. Front Plant Sci 10: 1008.

Sun Y, Guo H, Zhu-Salzman K, Ge F (2013) Elevated CO2 increases the abundance of the peach aphid on Arabidopsis by reducing jasmonic acid defenses. Plant Sci 210: $128-40$.

Suzuki T, Espana MU, Nunes MA, Zhurov V, Dermauw W, Osakabe M, Van Leeuwen T, Grbic M, Grbic V (2017) Protocols for the delivery of small molecules to the two-spotted spider mite, Tetranychus urticae. PLoS One 12 (7): e0180658. 
Thomma BP, Nelissen I, Eggermont K, Broekaert WF (1999) Deficiency in phytoalexin production causes enhanced susceptibility of Arabidopsis thaliana to the fungus Alternaria brassicicola. Plant J 19 (2): 163-71.

Tjallingii WF, Hogen Esch T (1993) Fine structure of aphid stylet routes in plant tissues in correlation with EPG signals. Physiological Entomology 18 (3): 317-328.

Ueda H, Nishiyama C, Shimada T, Koumoto Y, Hayashi Y, Kondo M, Takahashi T, Ohtomo I, Nishimura M, Hara-Nishimura I (2006) AtVAM3 is required for normal specification of idioblasts, myrosin cells. Plant Cell Physiol 47 (1): 16475.

Vik D, Mitarai N, Wulff N, Halkier BA, Burow M (2018) Dynamic Modeling of Indole Glucosinolate Hydrolysis and Its Impact on Auxin Signaling. Front Plant Sci 9: 550.

Wang J, Wu D, Wang Y, Xie D (2019) Jasmonate action in plant defense against insects. J Exp Bot 70 (13): 3391-3400.

Wasternack C, Strnad M (2018) Jasmonates: News on Occurrence, Biosynthesis, Metabolism and Action of an Ancient Group of Signaling Compounds. Int J Mol Sci $19(9)$.

Winter D, Vinegar B, Nahal H, Ammar R, Wilson GV, Provart NJ (2007) An "Electronic Fluorescent Pictograph" browser for exploring and analyzing largescale biological data sets. PLoS One 2 (8): e718.

Wittstock U, Halkier BA (2002) Glucosinolate research in the Arabidopsis era. Trends Plant Sci 7 (6): 263-70.

Xue J, Jørgensen M, Pihlgren U, Rask L (1995) The myrosinase gene family in Arabidopsis thaliana: gene organization, expression and evolution. Plant Mol Biol 27 (5): 911-22.

Zhao Y, Hull AK, Gupta NR, Goss KA, Alonso J, Ecker JR, Normanly J, Chory J, Celenza JL (2002) Trp-dependent auxin biosynthesis in Arabidopsis: involvement of cytochrome P450s CYP79B2 and CYP79B3. Genes Dev 16 (23): 3100-12.

Zhao Z, Zhang W, Stanley BA, Assmann SM (2008) Functional proteomics of Arabidopsis thaliana guard cells uncovers new stomatal signaling pathways. Plant Cell 20 (12): 3210-26.

Zhurov V, Navarro M, Bruinsma KA, Arbona V, Santamaria ME, Cazaux M, Wybouw N, Osborne EJ, Ens C, Rioja C, et al (2014) Reciprocal responses in the interaction between Arabidopsis and the cell-content-feeding chelicerate herbivore spider mite. Plant Physiol 164 (1): 384-99. 
bioRxiv preprint doi: https://doi.org/101101/2021.02.03.429630; this version posted February 3, 2021. The copyright holder for this preprint (which was not certified by peer review) is the author/funder, who has granted bioRxiv a license to display the preprint in perpetuity. It is made available under aCC-BY-ND 4.0 International license.
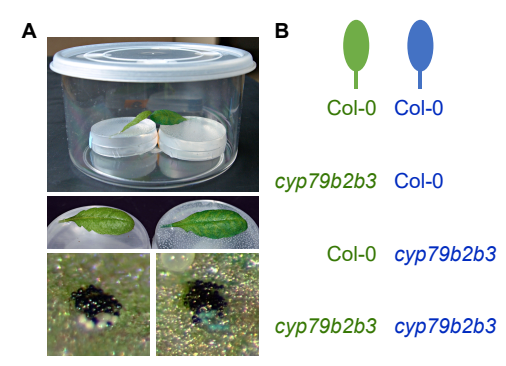

feces: non-stained $\square$ stained

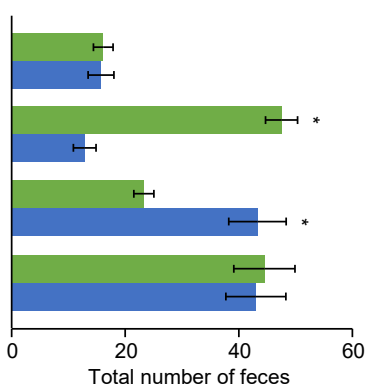

C

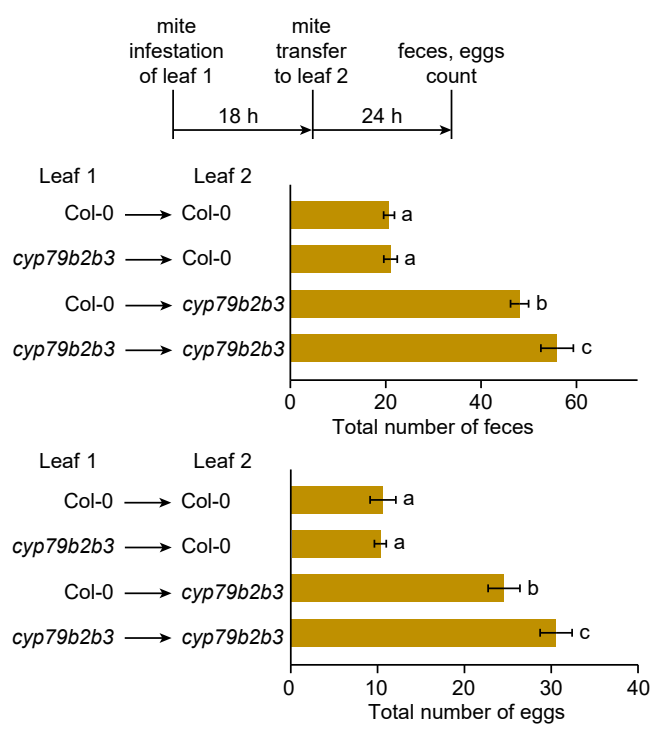

Figure 1 
bioRxiv preprint doi: https://doi.org/10.1101/2021.02.03.429630; this version posted February 3, 2021. The copyright holder for this preprint (which was not certified by peer review) is the author/funder, who has granted bioRxiv a license to display the preprint in perpetuity. It is made available under aCC-BY-ND 4.0 International license.

A

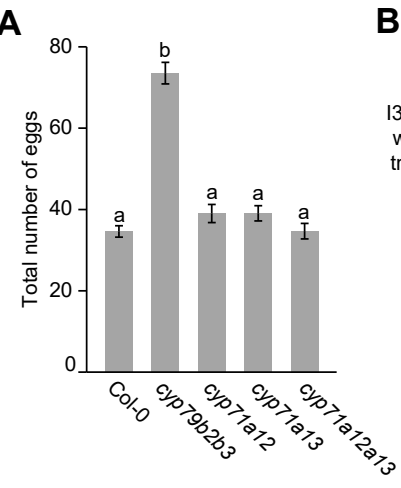

B

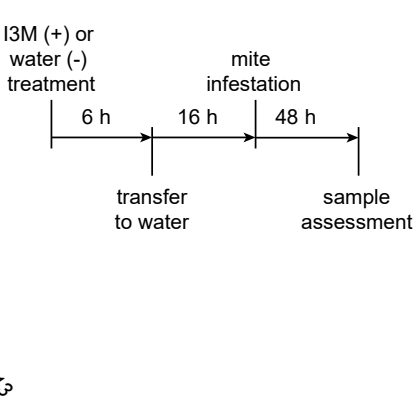

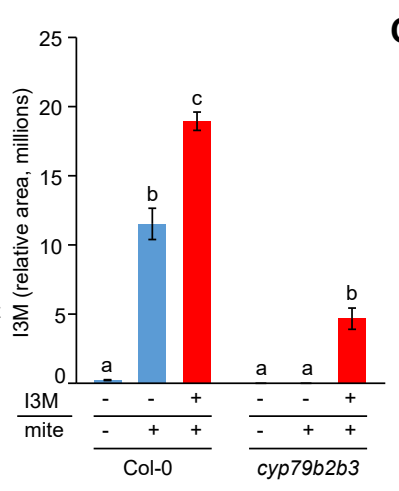

C

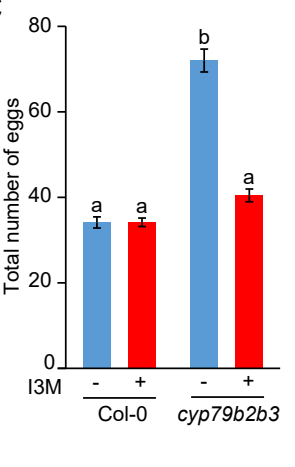

Figure 2 


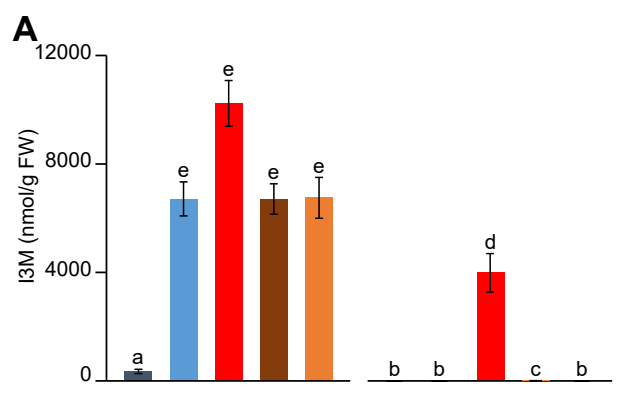

B
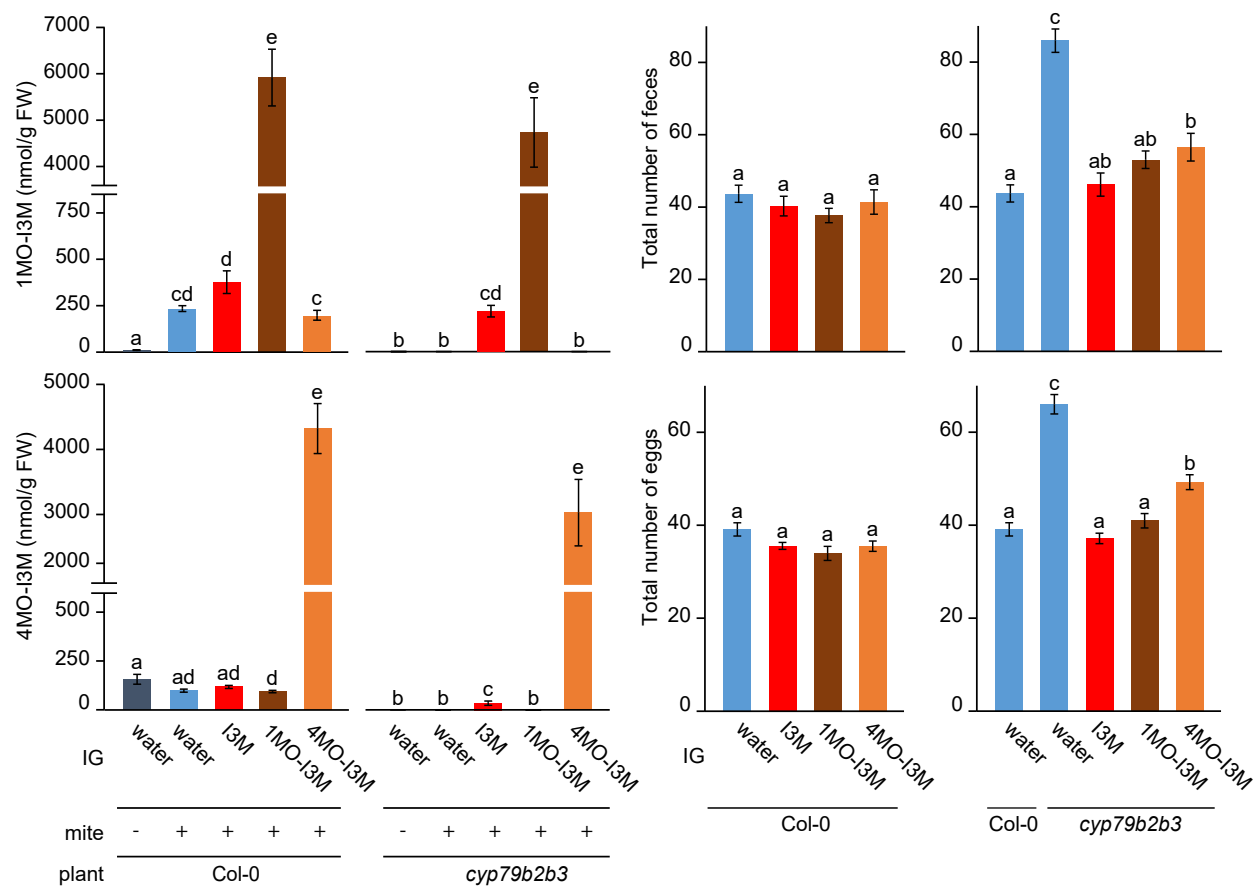

Figure 3 
bioRxiv preprint doi: https://doi.org/10.1101/2021.02.03.429630; this version posted February 3, 2021. The copyright holder for this preprint (which was not certified by peer review) is the author/funder, who has granted bioRxiv a license to display the preprint in perpetuity. It is made available under aCC-BY-ND 4.0 International license.

A
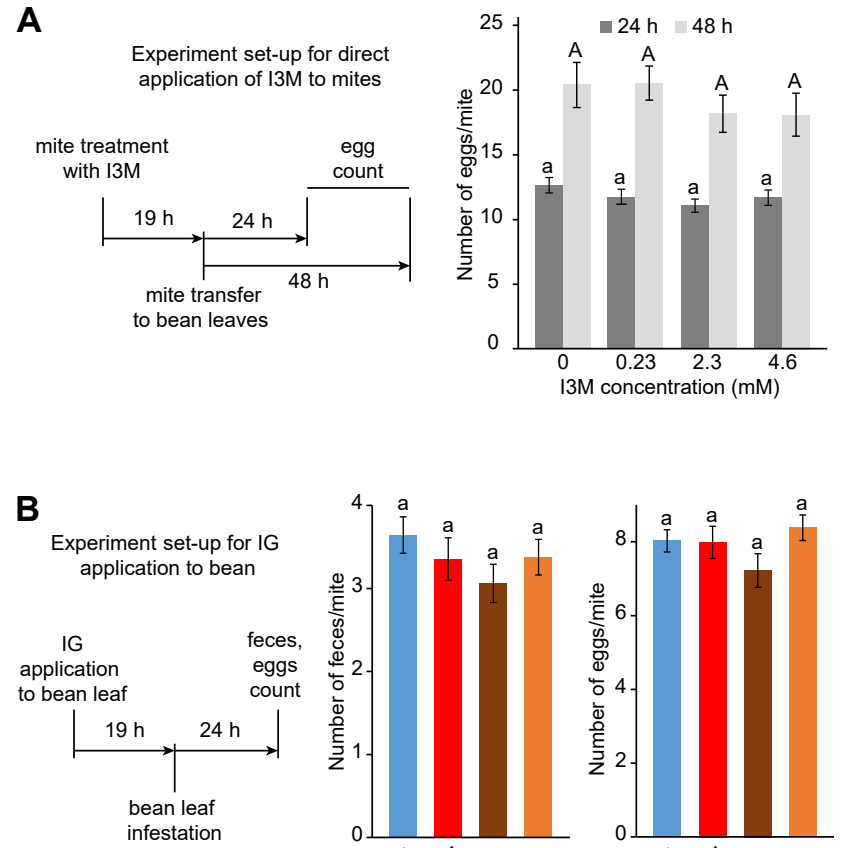

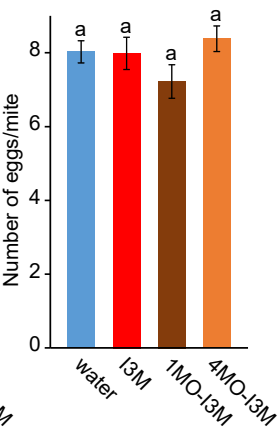

Figure 4 
bioRxiv preprint doi: https://doi.org/10.1101/2021.02.03.429630; this version posted February 3, 2021. The copyright holder for this preprint (which was not certified by peer review) is the author/funder, who has granted bioRxiv a license to display the preprint in perpetuity. It is made available under aCC-BY-ND 4.0 International license.
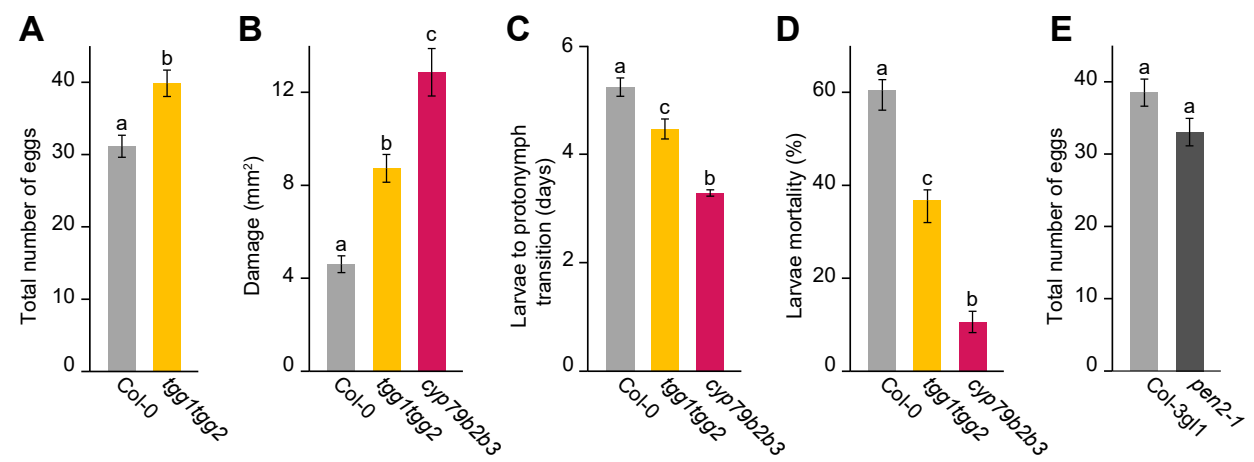

Figure 5 
bioRxiv preprint doi: https://doi.org/10.1101/2021.02.03.429630; this version posted February 3, 2021. The copyright holder for this preprint (which was not certified by peer review) is the author/funder, who has granted bioRxiv a license to display the preprint in perpetuity. It is made available under aCC-BY-ND 4.0 International license.

A
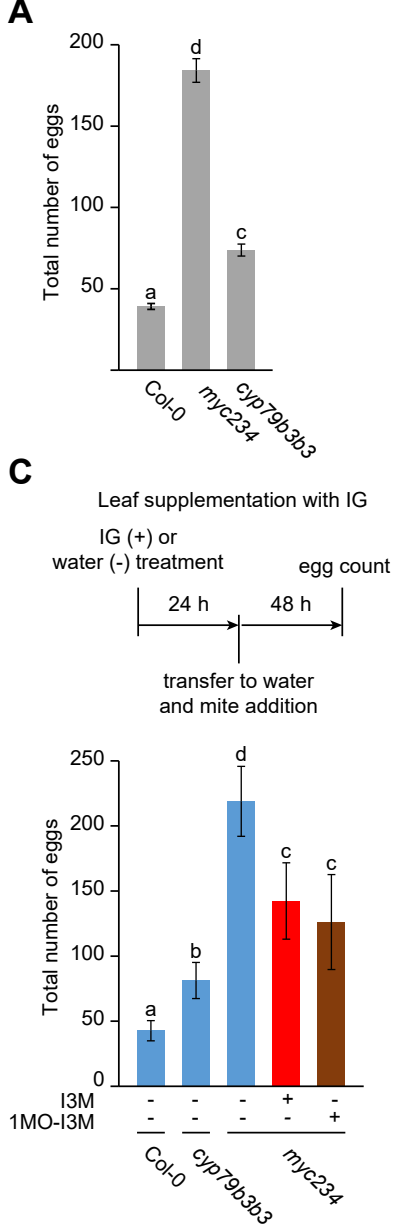

B
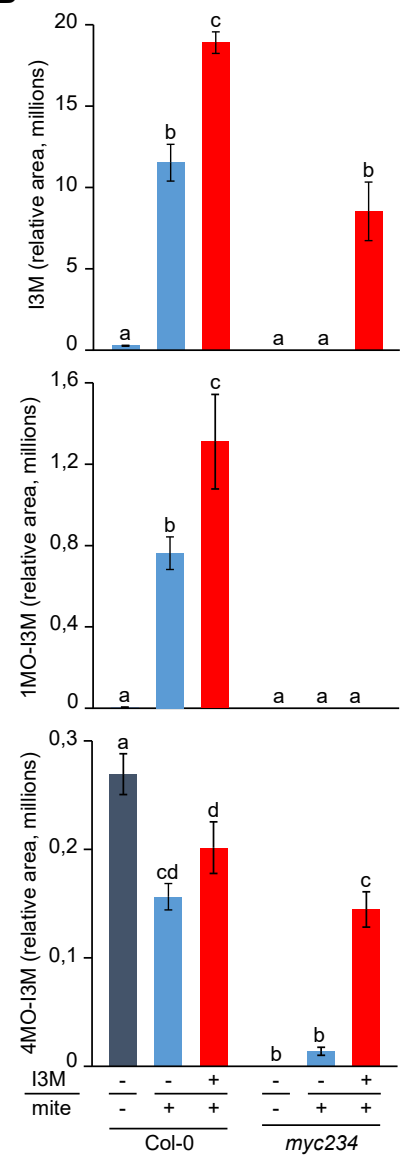

Figure 6 


\section{Parsed Citations}

Ahuja I, de Vos RC, Rohloff J, Stoopen GM, Halle KK, Ahmad SJ, Hoang L, Hall RD, Bones AM (2016) Arabidopsis myrosinases link the glucosinolate-myrosinase system and the cuticle. Sci Rep 6: 38990.

Google Scholar: Author Only Title Only Author and Title

Andersen TG, Nour-Eldin HH, Fuller VL, Olsen CE, Burow M, Halkier BA(2013) Integration of biosynthesis and long-distance transport establish organ-specific glucosinolate profiles in vegetative Arabidopsis. Plant Cell 25 (8): 3133-45.

Google Scholar: Author Only Title Only Author and Title

Appel HM, Fescemyer H, Ehlting J, Weston D, Rehrig E, Joshi T, Xu D, Bohlmann J, Schultz J (2014) Transcriptional responses of Arabidopsis thaliana to chewing and sucking insect herbivores. Front Plant Sci 5: 565.

Google Scholar: Author Only Title Only Author and Title

Barth C, Jander G (2006) Arabidopsis myrosinases TGG1 and TGG2 have redundant function in glucosinolate breakdown and insect defense. Plant J 46 (4): 549-62.

Google Scholar: Author Only Title Only Author and Title

Bednarek P, Pislewska-Bednarek M, Svatos A, Schneider B, Doubsky J, Mansurova M, Humphry M, Consonni C, Panstruga R, Sanchez-Vallet A, et al (2009) Aglucosinolate metabolism pathway in living plant cells mediates broad-spectrum antifungal defense.

Science 323 (5910): 101-6.

Google Scholar: Author Only Title Only Author and Title

Bensoussan N, Santamaria ME, Zhurov V, Diaz I, Grbić M, Grbić V (2016) Plant-Herbivore Interaction: Dissection of the Cellular Pattern of Tetranychus urticae Feeding on the Host Plant. Front Plant Sci 7: 1105.

Google Scholar: Author Only Title Only Author and Title

Beran F, Pauchet Y, Kunert G, Reichelt M, Wielsch N, Vogel H, Reinecke A, Svatoš A, Mewis I, Schmid D, et al (2014) Phyllotreta striolata flea beetles use host plant defense compounds to create their own glucosinolate-myrosinase system Proc Natl Acad Sci U S A111 (20): 7349-54.

Google Scholar: Author Only Title Only Author and Title

Bhat R, Vyas D (2019) Myrosinase: insights on structural, catalytic, regulatory, and environmental interactions. Crit Rev Biotechnol 39 (4): 508-523.

Google Scholar: Author Only Title Only Author and Title

Bjorkman R (1976) Properties and function of plant myrosinases. The Biology and Chemistry of the Cruciferae. J. G. Vaughan, A J. Macleod \& B. M. G. Jones, eds 1976: 191-205.

Google Scholar: Author Only Title Only Author and Title

Blažević I, Montaut S, Burčul F, Olsen CE, Burow M, Rollin P, Agerbirk N (2020) Glucosinolate structural diversity, identification, chemical synthesis and metabolism in plants. Phytochemistry 169: 112100.

Google Scholar: Author Only Title Only Author and Title

Bohman S, Staal J, Thomma BP, Wang M, Dixelius C (2004) Characterisation of an Arabidopsis-Leptosphaeria maculans pathosystem: resistance partially requires camalexin biosynthesis and is independent of salicylic acid, ethylene and jasmonic acid signalling. Plant $J$ 37 (1): 9-20.

Google Scholar: Author Only Title Only Author and Title

Bones AM, Rossiter JT (2006) The enzymic and chemically induced decomposition of glucosinolates. Phytochemistry 67 (11): $1053-67$.

Google Scholar: Author Only Title Only Author and Title

Brady SM, Burow M, Busch W, Carlborg Ö, Denby KJ, Glazebrook J, Hamilton ES, Harmer SL, Haswell ES, Maloof JN, et al (2015)

Reassess the t Test: Interact with Al Your Data via ANOVA Plant Cell 27 (8): 2088-94.

Google Scholar: Author Only Title Only Author and Title

Brown PD, Tokuhisa JG, Reichelt M, Gershenzon J (2003) Variation of glucosinolate accumulation among different organs and developmental stages of Arabidopsis thaliana. Phytochemistry 62 (3): 471-81.

Google Scholar: Author Only Title Only Author and Title

Burow M, Halkier BA(2017) How does a plant orchestrate defense in time and space? Using glucosinolates in Arabidopsis as case study. Curr Opin Plant Biol 38: 142-147.

Google Scholar: Author Only Title Only Author and Title

Cazaux M, Navarro M, Bruinsma KA, Zhurov V, Negrave T, Van Leeuwen T, Grbic V, Grbic M (2014) Application of two-spotted spider mite Tetranychus urticae for plant-pest interaction studies. J Vis Exp (89).

Google Scholar: Author Only Title Only Author and Title

Clay NK, Adio AM, Denoux C, Jander G, Ausubel FM (2009) Glucosinolate metabolites required for an Arabidopsis innate immune response. Science 323 (5910): 95-101.

Google Scholar: Author Only Title Only Author and Title

De Vos M, Van Oosten VR, Van Poecke RM, Van Pelt JA, Pozo MJ, Mueller MJ, Buchala AJ, Métraux JP, Van Loon LC, Dicke M, et al 
bioRxiv preprint doi: https://doi.org/10.1101/2021.02.03.429630; this version posted February 3, 2021. The copyright holder for this preprint

(which was not certified by peer review) is the author/funder, who has granted bioRxiv a license to display the preprint in perpetuity. It is made available under aCC-BY-ND 4.0 International license.

(2005) Signal signature and transcriptome changes of Arabidopsis during pathogen and insect attack. Mol Plant Microbe Interact 18 (9): 923-37.

Google Scholar: Author Only Title Only Author and Title

Fahey JW, Zalcmann AT, Talalay P (2001) The chemical diversity and distribution of glucosinolates and isothiocyanates among plants. Phytochemistry 56 (1): 5-51.

Google Scholar: Author Only Title Only Author and Title

Ferrari S, Galletti R, Denoux C, De Lorenzo G, Ausubel FM, Dewdney J (2007) Resistance to Botrytis cinerea induced in Arabidopsis by elicitors is independent of salicylic acid, ethylene, or jasmonate signaling but requires PHYTOALEXIN DEFICIENT3. Plant Physiol 144 (1): 367-79.

Google Scholar: Author Only Title Only Author and Title

Foyer CH, Verrall SR, Hancock RD (2015) Systematic analysis of phloem-feeding insect-induced transcriptional reprogramming in Arabidopsis highlights common features and reveals distinct responses to specialist and generalist insects. J Exp Bot 66 (2): 495-512. Google Scholar: Author Only Title Only Author and Title

Ghazy NA, Okamura M, Sai K, Yamakawa S, Hamdi FA, Grbic V, Suzuki T (2020) ALeaf-Mimicking Method for Oral Delivery of Bioactive Substances Into Sucking Arthropod Herbivores. Front Plant Sci 11: 1218.

Google Scholar: Author Only Title Only Author and Title

Giordanengo P, Brunissen L, Rusterucci C, Vincent C, van Bel A, Dinant S, Girousse C, Faucher M, Bonnemain JL (2010) Compatible plant-aphid interactions: how aphids manipulate plant responses. C R Biol 333 (6-7): 516-23.

Google Scholar: Author Only Title Only Author and Title

Glawischnig E (2007) Camalexin. Phytochemistry 68 (4): 401-6.

Google Scholar: Author Only Title Only Author and Title

Glindemann CP, Backenköhler A Strieker M, Wittstock U, Klahn P (2019) Synthesis and Biochemical Evaluation of an Artificial, Fluorescent Glucosinolate (GSL). Chembiochem 20 (18): 2341-2345.

Google Scholar: Author Only Title Only Author and Title

Howe GA, Jander G (2008) Plant immunity to insect herbivores. Annu Rev Plant Biol 59: 41-66.

Google Scholar: Author Only Title Only Author and Title

Husebye H, Chadchawan S, Winge P, Thangstad OP, Bones AM (2002) Guard cell- and phloem idioblast-specific expression of thioglucoside glucohydrolase 1 (myrosinase) in Arabidopsis. Plant Physiol 128 (4): 1180-8.

Google Scholar: Author Only Title Only Author and Title

Jeschke V, Kearney EE, Schramm K, Kunert G, Shekhov A, Gershenzon J, Vassão DG (2017) How Glucosinolates Affect Generalist Lepidopteran Larvae: Growth, Development and Glucosinolate Metabolism. Front Plant Sci 8: 1995.

Google Scholar: Author Only Title Only Author and Title

Kettles GJ, Drurey C, Schoonbeek HJ, Maule AJ, Hogenhout SA(2013) Resistance of Arabidopsis thaliana to the green peach aphid, Myzus persicae, involves camalexin and is regulated by microRNAs. New Phytol 198 (4): 1178-90.

Google Scholar: Author Only Title Only Author and Title

Kim JH, Jander G (2007) Myzus persicae (green peach aphid) feeding on Arabidopsis induces the formation of a deterrent indole glucosinolate. Plant J 49 (6): 1008-19.

Google Scholar: Author Only Title Only Author and Title

Kim JH, Lee BW, Schroeder FC, Jander G (2008) Identification of indole glucosinolate breakdown products with antifeedant effects on Myzus persicae (green peach aphid). Plant J 54 (6): 1015-26.

Google Scholar: Author Only Title Only Author and Title

Kissen R, Rossiter JT, Bones AM (2009) The 'mustard oil bomb': not so easy to assemble?! Localization, expression and distribution of the components of the myrosinase enzyme system Phytochem Rev 8: 69-86.

Google Scholar: Author Only Title Only Author and Title

Koroleva OA, Gibson TM, Cramer R, Stain C (2010) Glucosinolate-accumulating S-cells in Arabidopsis leaves and flower stalks undergo programmed cell death at early stages of differentiation. Plant J 64 (3): 456-69.

Google Scholar: Author Only Title Only Author and Title

Li M, Sack FD (2014) Myrosin idioblast cell fate and development are regulated by the Arabidopsis transcription factor FAMA, the auxin pathway, and vesicular trafficking. Plant Cell 26 (10): 4053-66.

Google Scholar: Author Only Title Only Author and Title

Lipka V, Dittgen J, Bednarek P, Bhat R, Wiermer M, Stein M, Landtag J, Brandt W, Rosahl S, Scheel D, et al (2005) Pre- and postinvasion defenses both contribute to nonhost resistance in Arabidopsis. Science 310 (5751): 1180-3.

Google Scholar: Author Only Title Only Author and Title

Lortzing T, Steppuhn A(2016) Jasmonate signalling in plants shapes plant-insect interaction ecology. Curr Opin Insect Sci 14: 32-39.

Google Scholar: Author Only Title Only Author and Title 
bioRxiv preprint doi: https://doi.org/10.1101/2021.02.03.429630; this version posted February 3, 2021. The copyright holder for this preprint (which was not certified by peer review) is the author/funder, who has granted bioRxiv a license to display the preprint in perpetuity. It is made available under aCC-BY-ND 4.0 International license.

Madsen SR, Olsen CE, Nour-Eldin HH, Halkier BA(2014) Elucidating the role of transport processes in leaf glucosinolate distribution.

Plant Physiol 166 (3): 1450-62.

Google Scholar: Author Only Title Only Author and Title

Mahmut D (2020) Conflicting perceptions of education in Canada: the perspectives of well-educated Muslim Uyghur immigrants.

Diaspora, Indigenous, and Minority Education: 1-13.

Google Scholar: Author Only Title Only Author and Title

Matern A, Böttcher C, Eschen-Lippold L, Westermann B, Smolka U, Döll S, Trempel F, Aryal B, Scheel D, Geisler M, et al (2019) A substrate of the ABC transporter PEN3 stimulates bacterial flagellin (flg22)-induced callose deposition in Arabidopsis thaliana. J Biol Chem 294 (17): 6857-6870.

Google Scholar: Author Only Title Only Author and Title

Meier K, Ehbrecht MD, Wittstock U (2019) Glucosinolate Content in Dormant and Germinating Arabidopsis thaliana Seeds Is Affected by Non-Functional Aleles of Classical Myrosinase and Nitrile-Specifier Protein Genes. Front Plant Sci $10: 1549$.

Google Scholar: Author Only Title Only Author and Title

Müller R, de Vos M, Sun JY, Sønderby IE, Halkier BA, Wittstock U, Jander G (2010) Differential effects of indole and aliphatic glucosinolates on lepidopteran herbivores. J Chem Ecol 36 (8): 905-13.

Google Scholar: Author Only Title Only Author and Title

Nakano RT, Piślewska-Bednarek M, Yamada K, Edger PP, Miyahara M, Kondo M, Böttcher C, Mori M, Nishimura M, Schulze-Lefert P, et al (2017) PYK10 myrosinase reveals a functional coordination between endoplasmic reticulum bodies and glucosinolates in Arabidopsis thaliana. Plant J 89 (2): 204-220.

Google Scholar: Author Only Title Only Author and Title

Nakazaki A, Yamada K, Kunieda T, Sugiyama R, Hirai MY, Tamura K, Hara-Nishimura I, Shimada T (2019) Leaf Endoplasmic Reticulum Bodies Identified in Arabidopsis Rosette Leaves Are Involved in Defense against Herbivory. Plant Physiol 179 (4): $1515-1524$.

Google Scholar: Author Only Title Only Author and Title

Nintemann SJ, Hunziker P, Andersen TG, Schulz A, Burow M, Halkier BA(2018) Localization of the glucosinolate biosynthetic enzymes reveals distinct spatial patterns for the biosynthesis of indole and aliphatic glucosinolates. Physiol Plant 163 (2): $138-154$.

Google Scholar: Author Only Title Only Author and Title

Pastorczyk M, Kosaka A, Pislewska-Bednarek M, Lopez G, Frerigmann H, Kulak K, Glawischnig E, Molina A, Takano Y, Bednarek P (2020) The role of CYP71A12 monooxygenase in pathogen-triggered tryptophan metabolism and Arabidopsis immunity. New Phytol 225 (1): 400-412.

Google Scholar: Author Only Title Only Author and Title

Pfalz M, Mukhaimar M, Perreau F, Kirk J, Hansen CI, Olsen CE, Agerbirk N, Kroymann J (2016) Methyl Transfer in Glucosinolate Biosynthesis Mediated by Indole Glucosinolate O-Methyltransferase 5. Plant Physiol 172 (4): 2190-2203.

Google Scholar: Author Only Title Only Author and Title

Rajniak J, Barco B, Clay NK, Sattely ES (2015) Anew cyanogenic metabolite in Arabidopsis required for inducible pathogen defence. Nature 525 (7569): 376-9.

Google Scholar: Author Only Title Only Author and Title

Rask L, Andréasson E, Ekbom B, Eriksson S, Pontoppidan B, Meijer J (2000) Myrosinase: gene family evolution and herbivore defense in Brassicaceae. Plant Mol Biol 42 (1): 93-113.

Google Scholar: Author Only Title Only Author and Title

Sanchez-Vallet A, Ramos B, Bednarek P, López G, Piślewska-Bednarek M, Schulze-Lefert P, Molina A(2010) Tryptophan-derived secondary metabolites in Arabidopsis thaliana confer non-host resistance to necrotrophic Plectosphaerella cucumerina fungi. Plant $\mathbf{J}$ 63 (1): 115-27.

Google Scholar: Author Only Title Only Author and Title

Schlaeppi K, Abou-Mansour E, Buchala A, Mauch F (2010) Disease resistance of Arabidopsis to Phytophthora brassicae is established by the sequential action of indole glucosinolates and camalexin. Plant J 62 (5): 840-51.

Google Scholar: Author Only Title Only Author and Title

Schweizer F, Fernández-Calvo P, Zander M, Diez-Diaz M, Fonseca S, Glauser G, Lewsey MG, Ecker JR, Solano R, Reymond P (2013) Arabidopsis basic helix-loop-helix transcription factors MYC2, MYC3, and MYC4 regulate glucosinolate biosynthesis, insect performance, and feeding behavior. Plant Cell 25 (8): 3117-32.

Google Scholar: Author Only Title Only Author and Title

Shirakawa M, Hara-Nishimura I (2018) Specialized Vacuoles of Myrosin Cells: Chemical Defense Strategy in Brassicales Plants. Plant Cell Physiol 59 (7): 1309-1316.

Google Scholar: Author Only Title Only Author and Title

Shirakawa M, Ueda H, Nagano AJ, Shimada T, Kohchi T, Hara-Nishimura I (2014) FAMA is an essential component for the differentiation of two distinct cell types, myrosin cells and guard cells, in Arabidopsis. Plant Cell 26 (10): 4039-52.

Google Scholar: Author Only Title Only Author and Title 
bioRxiv preprint doi: https://doi.org/10.1101/2021.02.03.429630; this version posted February 3, 2021. The copyright holder for this preprint (which was not certified by peer review) is the author/funder, who has granted bioRxiv a license to display the preprint in perpetuity. It is made available under aCC-BY-ND 4.0 International license.

Shroff R, Schramm K, Jeschke V, Nemes P, Vertes A, Gershenzon J, Svatos A(2015) Quantification of plant surface metabolites by matrix-assisted laser desorption-ionization mass spectrometry imaging: glucosinolates on Arabidopsis thaliana leaves. Plant $\mathrm{J} 81$ (6): 961-72.

Google Scholar: Author Only Title Only Author and Title

Sønderby IE, Burow M, Rowe HC, Kliebenstein DJ, Halkier BA(2010) Acomplex interplay of three R2R3 MYB transcription factors determines the profile of aliphatic glucosinolates in Arabidopsis. Plant Physiol 153 (1): 348-63.

Google Scholar: Author Only Title Only Author and Title

Sugiyama R, Hirai MY (2019) Atypical Myrosinase as a Mediator of Glucosinolate Functions in Plants. Front Plant Sci 10 : 1008. Google Scholar: Author Only Title Only Author and Title

Sun Y, Guo H, Zhu-Salzman K, Ge F (2013) Elevated CO2 increases the abundance of the peach aphid on Arabidopsis by reducing jasmonic acid defenses. Plant Sci 210: 128-40.

Google Scholar: Author Only Title Only Author and Title

Suzuki T, Espana MU, Nunes MA, Zhurov V, Dermauw W, Osakabe M, Van Leeuwen T, Grbic M, Grbic V (2017) Protocols for the delivery of small molecules to the two-spotted spider mite, Tetranychus urticae. PLoS One 12 (7): e0180658.

Google Scholar: Author Only Title Only Author and Title

Thomma BP, Nelissen I, Eggermont K, Broekaert WF (1999) Deficiency in phytoalexin production causes enhanced susceptibility of Arabidopsis thaliana to the fungus Alternaria brassicicola. Plant J 19 (2): 163-71.

Google Scholar: Author Only Title Only Author and Title

Tjallingii WF, Hogen Esch T (1993) Fine structure of aphid stylet routes in plant tissues in correlation with EPG signals. Physiological Entomology 18 (3): 317-328.

Google Scholar: Author Only Title Only Author and Title

Ueda H, Nishiyama C, Shimada T, Koumoto Y, Hayashi Y, Kondo M, Takahashi T, Ohtomo I, Nishimura M, Hara-Nishimura I (2006) AtVAM3 is required for normal specification of idioblasts, myrosin cells. Plant Cell Physiol 47 (1): $164-75$.

Google Scholar: Author Only Title Only Author and Title

Vik D, Mitarai N, Wulff N, Halkier BA, Burow M (2018) Dynamic Modeling of Indole Glucosinolate Hydrolysis and Its Impact on Auxin Signaling. Front Plant Sci 9: 550.

Google Scholar: Author Only Title Only Author and Title

Wang J, Wu D, Wang Y, Xie D (2019) Jasmonate action in plant defense against insects. J Exp Bot 70 (13): $3391-3400$.

Google Scholar: Author Only Title Only Author and Title

Wasternack C, Strnad M (2018) Jasmonates: News on Occurrence, Biosynthesis, Metabolism and Action of an Ancient Group of Signaling Compounds. Int J Mol Sci 19 (9).

Google Scholar: Author Only Title Only Author and Title

Winter D, Vinegar B, Nahal H, Ammar R, Wilson GV, Provart NJ (2007) An "Electronic Fluorescent Pictograph" browser for exploring and analyzing large-scale biological data sets. PLoS One 2 (8): e718.

Google Scholar: Author Only Title Only Author and Title

Wittstock U, Halkier BA(2002) Glucosinolate research in the Arabidopsis era. Trends Plant Sci 7 (6): $263-70$.

Google Scholar: Author Only Title Only Author and Title

Xue J, Jørgensen M, Pihlgren U, Rask L (1995) The myrosinase gene family in Arabidopsis thaliana: gene organization, expression and evolution. Plant Mol Biol 27 (5): 911-22.

Google Scholar: Author Only Title Only Author and Title

Zhao Y, Hull AK, Gupta NR, Goss KA, Alonso J, Ecker JR, Normanly J, Chory J, Celenza JL (2002) Trp-dependent auxin biosynthesis in Arabidopsis: involvement of cytochrome P450s CYP79B2 and CYP79B3. Genes Dev 16 (23): 3100-12.

Google Scholar: Author Only Title Only Author and Title

Zhao Z, Zhang W, Stanley BA, Assmann SM (2008) Functional proteomics of Arabidopsis thaliana guard cells uncovers new stomatal signaling pathways. Plant Cell 20 (12): 3210-26.

Google Scholar: Author Only Title Only Author and Title

Zhurov V, Navarro M, Bruinsma KA, Arbona V, Santamaria ME, Cazaux M, Wybouw N, Osborne EJ, Ens C, Rioja C, et al (2014) Reciprocal responses in the interaction between Arabidopsis and the cell-content-feeding chelicerate herbivore spider mite. Plant Physiol 164 (1): 384-99.

Google Scholar: Author Only Title Only Author and Title 